\title{
UK BUSINESS INVESTMENT: LONG-RUN ELASTICITIES AND SHORT-RUN DYNAMICS
}

\author{
Colin Ellis \\ Simon Price* \\ Bank of England \\ Threadneedle Street \\ London UK EC2R 8AH
}

\begin{abstract}
Theory tells us that output, the capital stock and the user cost of capital are cointegrated. From the capital accumulation identity, it also follows that the capital stock and investment have a long-run proportional relationship. This has been used to justify the estimation of investment equations embodying a long-run relation between investment and output, rather than between the capital stock and output. But the theory implies two cointegrating relationships exist, of which the investment-output relationship is a reduced form (and therefore itself cointegrating). The dynamic structure thus implies a multicointegrating framework, in which separate cointegrating relationships are identifiable. In this paper, a new investment equation is estimated in this framework, exploiting an internally constructed measure of the capital stock, and a long series for the weighted cost of capital. A CES production function is assumed, and a well-determined estimate of the elasticity of substitution is obtained by a variety of measures. The robust result is that the elasticity of substitution is significantly different from unity (the Cobb-Douglas case), at about 0.5 . Over-identifying restrictions on the long-run relationship are all accepted. Although the key long-run parameter (the elasticity of substitution) is highly robust to alternative specifications, single-equation investment relationships may obscure the dynamics. There is evidence that the Johansen method is over-sized, but given this a test for excluding the capital accumulation identity from the investment equation is much better than using a single equation ECM.
\end{abstract}

Keywords: investment, capital stock, identification, multicointegration.

JEL: C32, E22.

\footnotetext{
* Corresponding author: Colin.Ellis@bankofengland.co.uk. The views expressed in this paper are the authors', and may not necessarily represent those of the Bank of England. We are grateful for contributions and comments from Bank staff, especially Garry Young and Hasan Bakhshi, and from Peter Burridge. The authors alone are responsible for errors and omissions.
} 


\section{Introduction}

This paper re-examines the aggregate business investment relationship within a neoclassical framework. The reason for this is partly to exploit some new data, and partly to make a methodological point about the estimation of the investment decision in a cointegrating framework. In the process, we uncover a robust estimate of the user-cost elasticity, consistent with a sensible estimate of the elasticity of substitution. The empirical background is that researchers have found it difficult to find a role for the user cost of capital. Thus in research into UK investment published over the last decade, ${ }^{1}$ the roles of variously debt, profits, capacity utilisation and uncertainty have been used to augment $\mathrm{Q}^{2}$ and other models of investment. Moreover, although ONS publish a series for the stock of capital, researchers have tended to mistrust the series. ${ }^{3}$ Since Bean (1981), it has been common to exploit the steady state relationship between investment and the capital stock and model long-run investment, rather than capital. However, this approach conflates capital accumulation and investment dynamics into one equation.

In this paper, we take advantage of some new data and a new dynamic specification to return to the aggregate business investment equation. We use a real user cost of capital series, incorporating a weighted average cost of finance, that we push back to 1970. We also use estimates of the capital stock generated in-house at the Bank. We then pay particular attention to the endogenous dynamics of the system. The reason why this is an issue is because the capital stock, is determined by the capital accumulation identity (CAI). This identity is a difference equation explaining the growth of capital. It follows, as mentioned above, that there are steady state implications for the relationship between investment and capital. Thus there are two structural relationships that will hold in steady state. One is a relationship between the capital stock and its drivers (output and the user cost); this follows from the first order conditions of the profit maximising firm (FOC). The other is the steady state of the accumulation identity. In a non-stationary environment it may be helpful to estimate both of these relationships. As investment and the capital stock are linked via accumulation, we have an example of multicointegration. There are also interesting questions about the loadings (error correction coefficients) of the variables in the system, which have implications for the dynamics. And to anticipate the results, we find that we can successfully estimate a user cost Neoclassical model of

\footnotetext{
${ }^{1}$ For example, Bakhshi and Thompson (2002), Carruth, Henley and Dickerson (2000), Cuthbertson and Gasparro (1995) and Price (1995). Oliner et al (1995) estimate 'traditional' and Euler equation models for US investment, none of which do particularly well.

${ }^{2}$ Tobin's Q can be derived within the standard neoclassical framework.

${ }^{3}$ See Oulton (2001).
} 
investment where the key parameter, the elasticity of substitution, is both well determined and plausible.

In the next section we ask what the first order conditions and accumulation identity imply for the long-run. Then we spell out the implications for estimation within a vector error correction (VECM) framework, and estimate the model in Sections 4 and 5. Section 6 explores the finite sample properties of the methods with a Monte Carlo exercise, and Section 7 concludes.

\section{Theory; first order conditions and identities}

The key long-run relationship explaining investment in the Neoclassical model is the first order condition (FOC) for capital from a profit maximising firm. ${ }^{4}$

$$
k=y+\alpha-\beta r
$$

Here lower case denotes natural logs, $K$ is the capital stock, $Y$ output and $R$ denotes the real user cost of capital (RCC). ${ }^{5}$ Assuming a CES production function, $\beta$ is the elasticity of substitution between factors of production. Note that investment does not appear anywhere in the relationship: rather, the long-run relates capital (the cumulated depreciated stock of past investment flows) to output and RCC.

The CAI states that the stock of capital in any period is equal to the depreciated stock from the previous period plus (gross) investment. The CAI is shown in (2), where $I$ denotes investment and $\delta$ the depreciation rate.

$$
K_{t+1}=(1-\delta) K_{t}+I_{t}
$$

Bean (1981) uses this to substitute for capital. In the steady state (2) can be written as:

$$
K_{t}=\frac{I_{t}}{\delta+g_{t+1}^{K}}
$$

\footnotetext{
${ }^{4} \mathrm{We}$ assume that technical progress is only labour augmenting and that there is only one type of capital good.

${ }^{5}$ The data used in this note are described in the Data Appendix.
} 
where $g^{K}$ denotes the growth rate of capital. By substituting logged (3) into equation (1), we derive a long-run relationship (4) which links investment to output and the real user cost. ${ }^{6}$

$$
i=y+\alpha-\beta r+\ln \left(\delta+g^{K}\right) .
$$

This procedure was used in Bakhshi and Thompson (2002). The authors argue the long-run will not take account of past (accumulated) investment 'gaps', so they also included capacity utilisation as an integral control variable. ${ }^{7}$

It is not clear that this interpretation is the best dynamic representation of the data. It is helpful to think about (1) and (2) in a cointegrating framework. In what follows we assume that $k, i, y$ and $r$ are all $\mathrm{i}(1)$ variables, which is verified in practice. The FOC (1) defines a long-run relationship between $\{k, y, r\}$, and the CAI (2) also implies that $\{k, i\}$ cointegrate. Taking logs of (3), in the steady state

$$
k=i-\ln \left(\delta+g^{K}\right) .
$$

This is an example of multicointegration, a notion introduced by Granger and Lee (1991). Multicointegration is likely to occur wherever there are stock-flow relationships: for example, between consumption, income and wealth (as wealth is cumulated savings); or between product sales, output and inventories. In some cases, such as the latter, it can be helpful to use techniques for analysing I(2) series (see Engsted and Haldrup (1999)). However, in our case as $k$ is I(1), (3) implies that $i$ is also I(1) (or vice versa). This follows from non-zero depreciation. ${ }^{8}$ Moreover, not only are $\{k, i\}$ cointegrated, but we may also have a prior about the form of the error correction model (ECM). Lagged (2) may be re-written as:

$$
\frac{\Delta K_{t}}{K_{t-1}}=-\delta+\frac{I_{t-1}}{K_{t-1}}
$$

and this can be approximated as

\footnotetext{
${ }^{6} \mathrm{As} g^{K}$ and $\delta$ are stationary, in estimation they can be excluded from the long-run cointegrating vector. ${ }^{7}$ Bean (1981) argues that omitting such a variable may not lead to significant biases. Note that output itself is linked to capital via the production function and therefore incorporates a degree of integral control.

${ }^{8}$ As can be seen from the CAI (2), if $\delta$ were zero then if $I$ were i(1) then $K$ would be i(2).
} 


$$
\Delta k_{t} \approx \varphi_{0}+\varphi_{1}\left(i_{t-1}-k_{t-1}\right)
$$

where $\varphi_{i}$ are coefficients. In practice, this is a very close approximation. Thus the CAI implies $\{k, i\}$ cointegrate with associated vector $\{-1,1\}$, and (7) is, of course, an ECM representation.

Thus there are two long-run relationships in the data. (4) is now immediately interpretable as the reduced form of (1) and (5). It will therefore also be a cointegrating relationship. Whether this reduced form necessarily enters a single ECM as a unique relationship depends on the variables included in the cointegrating set; we return to this shortly.

\section{Modelling investment in a VECM framework}

From Section 1, we have four endogenous variables, $\{i, k, y, r\}$ and two co-integrating vectors (CVs) from equations (1) and (5). To re-state, these are:

$$
\begin{aligned}
& k=y+\alpha-\beta r \\
& i=k+\pi
\end{aligned}
$$

where $\alpha$ and $\pi$ are constants. In VECM notation our two-CV model can be written as:

$$
\Delta X_{t}=\Gamma(L) \Delta X_{t-1}+\Pi X_{t-1}+\Phi D
$$

where $L$ is the lag operator, $X$ is a matrix of $\mathrm{I}(1)$ variables, some of which may be weakly exogenous to the long-run relationship, and $D$ is a set of $\mathrm{I}(0)$ variables both weakly exogenous to and insignificant in the long-run cointegration space. $D$ may contain deterministic terms such as the constant and trend, and intervention dummies. For a four-variable, two-vector VECM the long-run can be decomposed as the reduced rank form

$$
\Pi X_{t-1}=\left[\begin{array}{ll}
\alpha_{11} & \alpha_{12} \\
\alpha_{21} & \alpha_{22} \\
\alpha_{31} & \alpha_{32} \\
\alpha_{41} & \alpha_{42}
\end{array}\right]\left[\begin{array}{llll}
\beta_{11} & \beta_{12} & \beta_{13} & \beta_{14} \\
\beta_{21} & \beta_{22} & \beta_{23} & \beta_{24}
\end{array}\right]\left[\begin{array}{c}
i \\
k \\
y \\
r
\end{array}\right]_{t-1}
$$


In this notation the $\beta_{i j}$ define the long-run relationships (the co-integrating vectors), and the $\alpha_{i j}$ the response of each variable to the two CVs (the 'loadings'). Although two vectors exist, it does not necessarily follow that all variables respond to all vectors. If a loading is zero, we have weak exogeneity: variable $i$ is weakly exogenous to the parameters in vector $j$ if $\alpha_{i j}=0$. Note that this does not imply that the variable is exogenous in the economic sense.

As an example of this, we showed above that the CAI may be approximated by (7), which is an ECM. It may well be that the firm's choice variable ( $i$ ) does not respond to disequilibrium in this vector. ${ }^{9}$ However, as the VECM is a transformation of the standard VAR in which contemporaneous terms have been substituted out, we are unlikely to have strong priors about the system dynamics; exogeneity is mainly an empirical question. From an econometric point of view, unless $k, y$ and $r$ are all weakly exogenous to the long-run relationships, efficient estimation requires the VECM to be estimated. But note that if this condition did hold, single equation estimation of the long-run parameters in an investment ECM would be unbiased. Moreover, there are sufficient restrictions to identify all the parameters. We would have

$$
\Delta i_{t}=\alpha_{0}+\text { dynamics }+\alpha_{1}\left(i_{t-1}-k_{t-1}\right)+\alpha_{2}\left(k_{t-1}-y_{t-1}-\beta r_{t-1}\right) .
$$

\section{VECM results}

In this section we estimate the structure outlined above using the Johansen method. This is maximum likelihood, and assumes Gaussian errors, so it is important to ensure that the residuals in the underlying VAR are normal and white noise. In order to determine the lag structure, we began by estimating an unrestricted VAR. ${ }^{10}$ Lag order selection criteria suggested two lags, ${ }^{11}$ but on the serial correlation criteria, eight lags were required. There is still some evidence of serial correlation with a significant LM test at 6 lags, but the test is then short of degrees of freedom. The residual correlograms reveal no problems. ${ }^{12}$ This number of lags implies that the VAR is almost certainly overparameterised, which reduces the power of the tests. Thus we should err on the side of caution when determining the number of cointegrating vectors (use lower critical values). But the consequences of using too low a lag length

\footnotetext{
9 'Disequilibrium' here is interpreted as an approximation error.

${ }^{10}$ Results are reported using dummies for 1985 Q1 and Q2 for a change in the tax allowances. All estimation is over the full sample (1970 Q2 - 2001 Q4), adjusted for lags.

${ }^{11}$ But information criteria are not helpful in determining lag lengths in cointegrating VECMs: Cheung and Lai (1993).

${ }^{12}$ Residuals for the system are shown in Annex 2.
} 
are usually thought to be more severe. ${ }^{13}$ On diagnostic failures in a cointegrating context, Hendry and Juselius (2000) conclude that '[s]imulation studies have demonstrated that statistical inference is sensitive to the validity of some of the assumptions, such as, parameter non-constancy, serially-correlated residuals and residual skewness, while moderately robust to others, such as excess kurtosis (fattailed distributions) and residual heteroscedasticity.' On normality, each equation in the VAR comfortably passed tests for skewness, but there was evidence for excess kurtosis at the $1 \%$ level in the $r$ and $i$ equations, and at the $10 \%$ level in the $y$ equation. While the kurtosis result should lead to caution in interpreting results, there is no reason to suppose inference is fatally flawed.

\subsection{Results for full variable set $\{\mathrm{i}, \mathrm{k}, \mathrm{y}, \mathrm{r}\}$}

Cointegration test results for the four endogenous variables are shown in Table 1, and we conclude that there are indeed 2 cointegrating vectors. With four variables and two cointegrating vectors, we need two restrictions per vector for exact identification. (1) and (5a) allow us to over-identify both vectors, and these (over-identifying) restrictions are accepted by the data when we impose them (Table 2).

Only one parameter of interest is freely estimated in the co-integrating vectors, the elasticity of substitution, which is found to be 0.487 . Remarkably, this is consistent with a wide variety of single equation estimates we examined (i.e. Engle-Granger, DOLS) with varying dependent long-run variables (capital vs investment): these estimates were all in the range $0.43-0.51 .^{14}$ This is in the region of other estimates; i.e., below NIGEM's estimate of 0.66 for the UK (see NIESR 2002), but above Chirinko et al's (2002) panel-based estimate of 0.40 for the US. ${ }^{15}$

\footnotetext{
${ }^{13}$ There are many Monte Carlo studies of finite sample properties of the Johansen and other tests for cointegration, examining deviations form the maintained assumptions. Much of this literature is summarised in Maddala and Kim (1998). Results can be sensitive to the order in which assumptions about constants, trends and exogeneity are tested: see Greenslade et al (2002). We are guided by Hendry and Juselius (2000).

${ }^{14}$ In addition, both single equation and VECM estimates (not reported) of the elasticity using alternative user cost measures, ie altering the expected change in the relative price term (see Data Appendix), were mainly in this range.

${ }^{15}$ NIGEM's estimate for the US is 0.57 .
} 
Table 1: Co-integration tests: $\{i, k, y, r\}$

\begin{tabular}{|l|cc|}
\hline $\begin{array}{l}\text { Number of CVs } \\
\text { (null hypothesis) }\end{array}$ & $\begin{array}{c}\text { Trace } \\
\text { statistic }\end{array}$ & $\begin{array}{c}\text { Max-Eigen } \\
\text { statistic }\end{array}$ \\
\hline None & $60.5^{* *}$ & $28.3^{*}$ \\
At most 1 & $32.2^{*}$ & $21.8^{*}$ \\
At most 2 & 10.4 & 9.8 \\
\hline
\end{tabular}

$*(* *)$ indicates rejection of null at 5\% (1\%) significance level.

\section{Table 2: Estimated long-run of VECM}

Sample: 1972:3 2001:4

LR test for binding restrictions $($ rank $=2)$ :

Chi-square(3) $\quad 4.038728$

Probability 0.257312

\begin{tabular}{|c|c|c|c|c|}
\hline Cointegrating Eq: & $\begin{array}{c}\text { CointEq1 } \\
\text { CAI }\end{array}$ & $\begin{array}{c}\text { CointEq2 } \\
\text { FOC } \\
\end{array}$ & & \\
\hline $\mathrm{r}(-1)$ & 0.000000 & $\begin{array}{c}-0.486718 \\
(0.04250) \\
{[-11.4525]}\end{array}$ & & \\
\hline $\mathrm{i}(-1)$ & -1.000000 & 0.000000 & & \\
\hline$y(-1)$ & 0.000000 & 1.000000 & & \\
\hline $\mathrm{k}(-1)$ & 1.000000 & -1.000000 & & \\
\hline Constant & -4.032444 & 0.092759 & & \\
\hline Error Correction: & $\Delta \mathrm{r}$ & $\Delta \mathrm{i}$ & $\Delta y$ & $\Delta \mathrm{k}$ \\
\hline $\begin{array}{l}\text { CointEq1 loading } \\
\text { (CAI) }\end{array}$ & $\begin{array}{r}0.956681 \\
(0.31915) \\
{[2.99763]}\end{array}$ & $\begin{array}{c}0.017525 \\
(0.28545) \\
{[0.06140]}\end{array}$ & $\begin{array}{c}-0.010137 \\
(0.08062) \\
{[-0.12574]}\end{array}$ & $\begin{array}{r}-0.006984 \\
(0.00534) \\
{[-1.30743]}\end{array}$ \\
\hline $\begin{array}{c}\text { CointEq2 loading } \\
\text { (FOC) }\end{array}$ & $\begin{array}{c}0.403018 \\
(0.09907) \\
{[4.06792]}\end{array}$ & $\begin{array}{r}0.068393 \\
(0.08861) \\
{[0.77183]}\end{array}$ & $\begin{array}{c}0.039719 \\
(0.02503) \\
{[1.58711]}\end{array}$ & $\begin{array}{r}8.74 \mathrm{E}-06 \\
(0.00166) \\
{[0.00527]}\end{array}$ \\
\hline
\end{tabular}

Given we have identified cointegrating vectors, we can now examine weak exogeneity (WE) of the endogenous variables with respect to the two vectors. From Table 2 the obvious candidates are the $\Delta i$ with respect to the first vector (CAI) and the $\Delta k$ equation with respect to the second (FOC); the $t$ statistics in both cases are as close to zero as we are likely to observe: 0.06 and 0.01 respectively. Moreover, as we spell out shortly, these zero restrictions are precisely what we would expect. The $\Delta y$ loading with respect to CAI is also very insignificant. The resulting estimates when we impose these restrictions (as well as the CV restrictions) are shown in Table 3. The full set of restrictions is comfortably accepted, and all remaining loadings are now significant. ${ }^{16}$

\footnotetext{
${ }^{16}$ When we followed Greenslade et al (2002) and tested for co-integration imposing these weak exogeneity restrictions, our results were unaffected; ie, were as shown in Table 1.
} 


\section{Table 3: VECM estimates with loading restrictions}

Sample: 1972:3 2001:4

LR test for binding restrictions $($ rank $=2)$ :

Chi-square(6) $\quad 4.081410$

Probability 0.665660

\begin{tabular}{|c|c|c|c|c|}
\hline Cointegrating Eq: & $\begin{array}{c}\text { CointEq1 } \\
\text { CAI } \\
\end{array}$ & $\begin{array}{c}\text { CointEq2 } \\
\text { FOC } \\
\end{array}$ & & \\
\hline $\mathrm{r}(-1)$ & 0.000000 & $\begin{array}{r}-0.487096 \\
(0.04229) \\
{[-11.5184]}\end{array}$ & & \\
\hline $\mathrm{i}(-1)$ & -1.000000 & 0.000000 & & \\
\hline$y(-1)$ & 0.000000 & 1.000000 & & \\
\hline $\mathrm{k}(-1)$ & 1.000000 & -1.000000 & & \\
\hline Constant & -4.032444 & 0.091444 & & \\
\hline Error Correction: & $\Delta \mathrm{r}$ & $\Delta \mathrm{i}$ & $\Delta \mathrm{y}$ & $\Delta \mathrm{k}$ \\
\hline $\begin{array}{c}\text { CointEq1 loading } \\
\text { CAI }\end{array}$ & $\begin{array}{c}0.952169 \\
(0.31764) \\
{[2.99763]}\end{array}$ & $\begin{array}{l}0.000000 \\
(0.00000) \\
{[\mathrm{NA}]}\end{array}$ & $\begin{array}{l}0.000000 \\
(0.00000) \\
{[\mathrm{NA}]}\end{array}$ & $\begin{array}{r}-0.007275 \\
(0.00187) \\
{[-3.88294]}\end{array}$ \\
\hline $\begin{array}{c}\text { CointEq2 loading } \\
\text { FOC }\end{array}$ & $\begin{array}{r}0.401817 \\
(0.09868) \\
{[4.07184]}\end{array}$ & $\begin{array}{r}0.067316 \\
(0.03109) \\
{[2.16511]}\end{array}$ & $\begin{array}{c}0.042108 \\
(0.01752) \\
{[2.40312]}\end{array}$ & $\begin{array}{l}0.000000 \\
(0.00000) \\
{[\mathrm{NA}]}\end{array}$ \\
\hline
\end{tabular}

The loading coefficient on capital to the first vector (CAI) is small numerically. But the estimate of 0.007 is plausible. To see why this is the case, recall from Section 2 that the CAI can be re-written as

$$
\frac{\Delta K_{t}}{K_{t-1}}=-\delta+\frac{I_{t-1}}{K_{t-1}}
$$

or approximately

$$
\Delta k_{t}=-\delta+\frac{I_{t-1}}{K_{t-1}} .
$$

Our ECM approximation is

$$
\Delta k_{t} \approx \varphi_{0}+\varphi_{1}\left(i_{t-1}-k_{t-1}\right)
$$

What value of $\varphi_{1}$ is required to ensure that that $\frac{d \Delta k_{t}}{d I_{t}}$ are approximately equal in these two relationships? This will be $\frac{d g^{K}}{d I}=\varphi_{1} \frac{1}{I}$. So this implies $\varphi_{1}=\frac{I}{K}$. Over the sample period the mean ratio of investment to capital is 0.0178 . With no lagged 
dependent variables in a regression of (7) this is the coefficient we should expect. ${ }^{17}$ Where they are present, we need to calculate the long-run coefficient, which in our case is 0.0164 , close to the sample average. So this seemingly small loading coefficient is about what we would expect, given the data.

Adjustment takes place via the user cost as well as through quantities. Recall that if the CAI ECM term is positive then the capital stock is below the long-run value: equivalently, investment is above the long-run value. If demand for investment goods is above equilibrium, we might expect the price of investment goods to be rising. Similarly, to use a Keynesian phrase, the excess demand for loanable funds implied by high investment would put upward pressure on the interest rate. Both these factors mean the loading on the CAI vector in the ECM for $r$ should be positive, which it is.

The output loading is positive, which has no obvious interpretation. But it is hard to judge details of the dynamic process from the single equation loadings, as all the dynamics in the system are important. ${ }^{18}$ Thus Chart 1 reports the impulse responses of the endogenous variables to a one standard deviation shock to the real user cost $(r) .{ }^{19}$ The vertical scale is $\log$ difference (ie approximately $\%$ difference/100), and the horizontal scale is time periods in quarters. The response of capital is fairly slow, with the maximum (overshooting) effect occurring after six years with the further unwind persisting beyond this. This drawn-out response is mirrored in the investment and output responses. Part of this is likely to be linked to the fact that the real user cost does not return to equilibrium until at least 30 quarters after the initial shock.

\footnotetext{
${ }^{17}$ And in fact a simple OLS regression produces a coefficient of 0.0168 .

${ }^{18}$ The system is shown in full in Annex 2.

${ }^{19}$ We use a Cholesky ordering where the user cost is placed first.
} 


\section{Chart 1: System impulse responses}

Response to Cholesky One S.D. Innovations
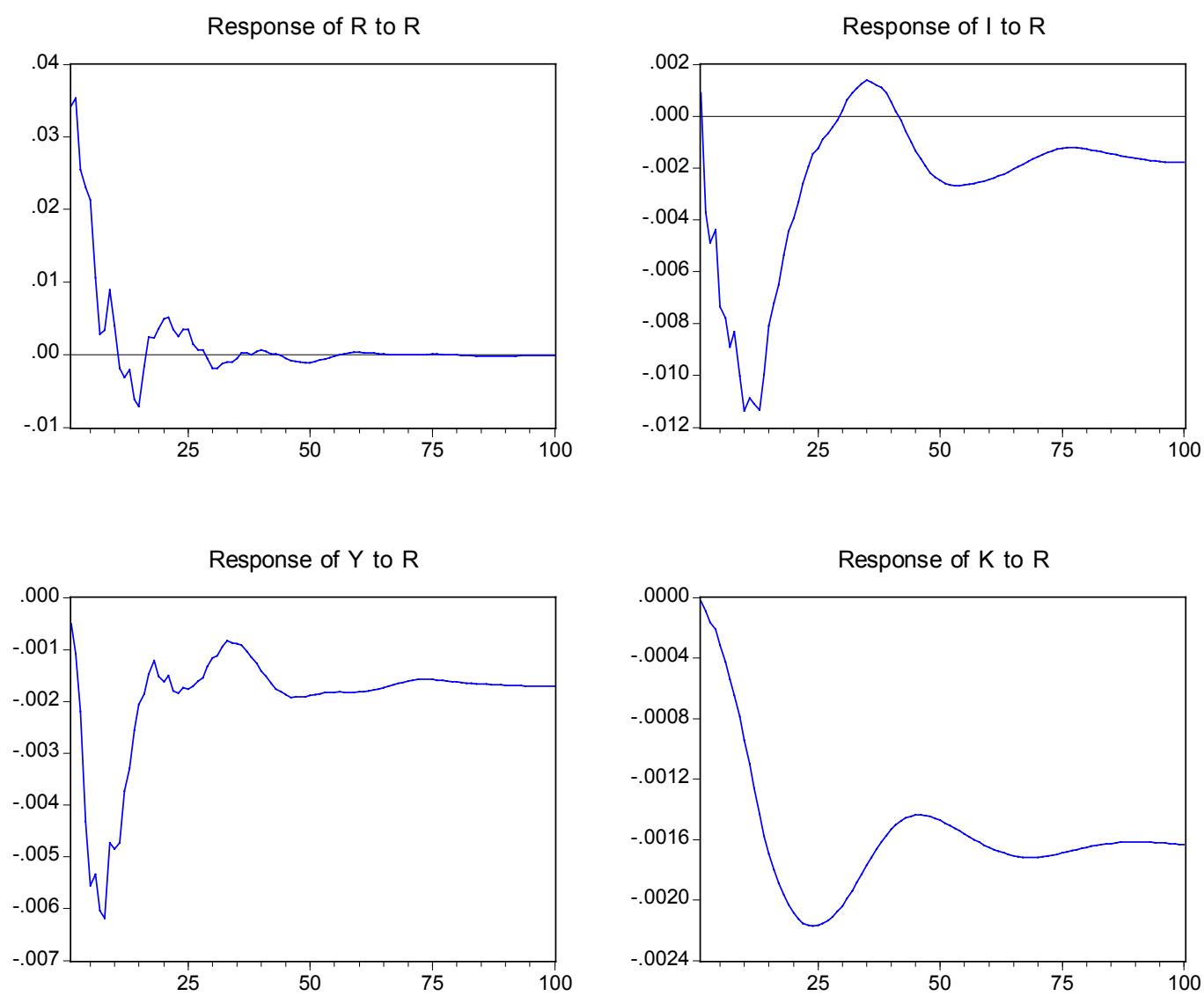

\subsection{SUR VECM results.}

We have established the existence of two cointegrating vectors and tested the overidentifying restrictions implied by theory. Nevertheless, with eight lags the dynamics of the system are grossly overparameterised. Thus we looked for a parsimonious restriction of the system, estimated by Seemingly Unrelated Regression (SUR). Full results are shown in Annex 2. When we tested down without imposing the weak exogeneity restrictions, the dynamic capital equation responds to both cointegrating vectors. However, investment is still weakly exogenous to the capital accumulation identity.

\subsection{Results for restricted cointegrating variable sets: irreducible cointegration}

Our model predicts that two cointegrating vectors exist among the four variables, and we have successfully identified them using the overidentifying restrictions from theory. It should be clear, however, that if we restrict attention to limited sets of variables then it should be possible to estimate unique vectors, albeit with a possible 
loss of efficiency. This idea was formalised and explored by Davidson $(1994,1998)$ as the notion of 'irreducible cointegration'. An irreducible cointegrating relation is one from which no variable can be omitted without loss of the cointegration property. Such relations may be structural or reduced form. The advantage of the procedure he suggests is that, under certain circumstances, when the model is overidentified, it enables the researcher to obtain information about the underlying structure directly from the data. However, as in our case, this will not always be true: theory is still required. If our approach is correct, we should find evidence for unique structural and irreducible cointegrating vectors in each of the sets $\{k, y, r\}$ and $\{i, k\}$, from (1) and (5). Tables 4 and 5 reveal support for this. ${ }^{20}$ Moreover, the restrictions on the two vectors are accepted ( $p$ values of 0.31 and 0.99 for FOC and CAI respectively). The pattern, significance and rough magnitudes of the loadings are consistent with those from the full system. The reduced form (4) also implies that $\{i, y, r\}$ should constitute an irreducible cointegrating set. Table 6 gives the test results. Strictly, they fail to reject the null of no cointegration, but the failure is very marginal. So this last result suggests that the Bean reduced form specification will work. Nevertheless, the fact that we are estimating a reduced form specification means that the adjustment dynamics conflate the capital adjustment and accumulation.

Table 4: Co-integration tests: $\{k, y, r\}$

\begin{tabular}{|l|cc|}
\hline $\begin{array}{l}\text { Null hypothesis: } \\
\text { no. of cointegrating } \\
\text { equations }\end{array}$ & $\begin{array}{c}\text { Trace } \\
\text { statistic }\end{array}$ & $\begin{array}{c}\text { Max-Eigen } \\
\text { statistic }\end{array}$ \\
\hline None & $35.9^{* *}$ & $21.2^{*}$ \\
At most 1 & 14.7 & 13.5 \\
\hline
\end{tabular}

$*(* *)$ indicates rejection of null at $5 \%(1 \%)$ level

Table 5: Co-integration tests: $\{k, i\}$

\begin{tabular}{|l|cc|}
\hline $\begin{array}{l}\text { Null hypothesis: } \\
\text { no. of cointegrating } \\
\text { equations }\end{array}$ & $\begin{array}{c}\text { Trace } \\
\text { statistic }\end{array}$ & $\begin{array}{c}\text { Max-Eigen } \\
\text { statistic }\end{array}$ \\
\hline None & $18.5^{*}$ & $18.4^{*}$ \\
\hline
\end{tabular}

$*(* *)$ indicates rejection of null at $5 \%(1 \%)$ level

\footnotetext{
${ }^{20}$ The coefficient restrictions are essential for the irreducibility argument, as without them there is evidence that $\{y, r\}$ and $\{k, r\}$ cointegrate, which have no sensible economic interpretations. Thus we effectively argue that $\{i-y, r\},\{i-k\}$ and $\{k-y, r\}$ form conditional irreducible cointegrating sets.
} 
Table 6: Co-integration tests: $\{i, y, r\}$

\begin{tabular}{|l|cc|}
\hline $\begin{array}{l}\text { Null hypothesis: } \\
\text { no. of cointegrating } \\
\text { equations }\end{array}$ & $\begin{array}{c}\text { Trace } \\
\text { statistic }\end{array}$ & $\begin{array}{c}\text { Max-Eigen } \\
\text { statistic }\end{array}$ \\
\hline None & 29.5 & 17.9 \\
At most 1 & 11.6 & 10.4 \\
\hline
\end{tabular}

$*(* *)$ indicates rejection of null at $5 \%(1 \%)$ level

\section{Impulse responses}

The results we have obtained thus far imply that investment equilibrates the capital stock equilibrium condition. This automatically embodies an integral control mechanism through the capital accumulation identity. The cointegrating relationship implied by the capital accumulation identity does not equilibrate through the investment equation. However, no variables are weakly exogenous with respect to either of the cointegrating relationships so efficient estimation requires full system estimation. But given the theory and results in Table 6 if the cointegrated set excludes capital a single equation might be estimated. ${ }^{21}$ Table 7 reports the restricted equation. The loading is very similar to that obtained in the estimation underlying Table 6 (0.11 with t ratio -2.44$)$. Table 8 reports the comparable results of using the long-run VECM results, re-estimated parsimoniously by OLS.

\section{Table 7: Reduced form}

Dependent Variable: $\Delta \mathrm{i}$

Sample(adjusted): 1972:4 2001:4

Included observations: 117 after adjusting endpoints

\begin{tabular}{|c|c|c|c|c|}
\hline Variable & Coefficient & Std. Error & $\mathrm{t}$-Statistic & Prob. \\
\hline $\mathrm{C}$ & -0.492641 & 0.117121 & -4.206240 & 0.0001 \\
\hline$\Delta \mathrm{i}(-2)$ & 0.134353 & 0.078661 & 1.707989 & 0.0905 \\
\hline$\Delta \mathrm{i}(-3)$ & 0.239688 & 0.079605 & 3.010960 & 0.0032 \\
\hline$\Delta \mathrm{i}(-4)$ & 0.262899 & 0.080311 & 3.273512 & 0.0014 \\
\hline$\Delta \mathrm{r}(-1)$ & -0.099919 & 0.059572 & -1.677278 & 0.0964 \\
\hline $\mathrm{i}(-1)-\mathrm{y}(-1)$ & -0.127121 & 0.029159 & -4.359601 & 0.0000 \\
\hline$r(-1) *$ & 0.475670 & 0.097439 & 4.881730 & 0.0000 \\
\hline D85_1 & 0.080922 & 0.029278 & 2.763893 & 0.0067 \\
\hline D85_1(-1) & -0.146838 & 0.029277 & -5.015513 & 0.0000 \\
\hline R-squared & 0.381152 & \multicolumn{2}{|c|}{ Mean dependent var } & 0.008681 \\
\hline Adjusted R-squared & 0.335311 & \multicolumn{2}{|c|}{ S.D. dependent var } & 0.035305 \\
\hline S.E. of regression & 0.028784 & \multicolumn{2}{|c|}{ Akaike info criterion } & -4.184224 \\
\hline Sum squared resid & 0.089477 & \multicolumn{2}{|c|}{ Schwarz criterion } & -3.971749 \\
\hline Log likelihood & 253.7771 & \multicolumn{2}{|c|}{ F-statistic } & 8.314728 \\
\hline Durbin-Watson stat & 1.983020 & \multicolumn{2}{|c|}{ Prob(F-statistic) } & 0.000000 \\
\hline
\end{tabular}

* Long run value.

\footnotetext{
${ }^{21}$ The specification in Table 7 differs from that in the Annex A1 as there is no capacity utilisation term, included for comparability with previous Bank work, but the long-run parameter and adjustment terms are very close.
} 
Table 8: Single equation from VECM long-run results

Dependent Variable: $\Delta \mathrm{i}$

Sample: 1972:3 2001:4

Included observations: 118

\begin{tabular}{crrrr}
\hline \hline & Coefficient & Std. Error & t-Statistic & Prob. \\
\hline \hline FOC* & $\mathbf{0 . 0 9 4 1 1 8}$ & 0.037095 & 2.537258 & 0.0126 \\
$\Delta \mathrm{i}(-7)$ & 0.284577 & 0.076495 & 3.720192 & 0.0003 \\
$\Delta \mathrm{y}(-5)$ & 0.267220 & 0.276990 & 0.964729 & 0.3368 \\
$\Delta \mathrm{k}(-7)$ & -6.201872 & 1.507702 & -4.113460 & 0.0001 \\
Constant & 0.061362 & 0.014359 & 4.273532 & 0.0000 \\
1985:1 dummy & 0.075808 & 0.028814 & 2.630983 & 0.0097 \\
1985:1 dummy lagged & -0.153400 & 0.028835 & -5.319945 & 0.0000 \\
\hline \hline R-squared & 0.391253 & Mean dependent var & 0.008487 \\
Adjusted R-squared & 0.358348 & S.D. dependent var & 0.035217 \\
S.E. of regression & 0.028210 & Akaike info criterion & -4.240809 \\
Sum squared resid & 0.088333 & Schwarz criterion & -4.076447 \\
Log likelihood & 257.2077 & Durbin-Watson stat & 2.150894 \\
\hline * Defined as in Table 3. Normalisation on $k$ & &
\end{tabular}

* Defined as in Table 3. Normalisation on $-k$.

In order to calculate the different responses of investment and capital under these approaches, we constructed two models, each of which comprised the dynamic investment equation and the capital accumulation identity. In specifying these models, we treated $y$ and $r$ as exogenous, as we are concerned here purely with the investment and capital stock dynamics. Thus the responses differ from those in Chart 1. Our impulse was a permanent $+1 \%$ shock to the level of the real user cost $(R)$.

The estimated response of capital under the two methods is shown below in Chart 2, with forecast-relevant periods singled out in Table 9. In each case the long-run adjustment of capital reflects the estimated elasticity of substitution in each model, as it must, which are similar in each model. Due to the small size of investment relative to the capital stock (investment represents just under $2 \%$ of the capital stock), in both cases it takes a considerable length of time to reach the long-run.

Table 9: Impulse responses at forecast horizons

\begin{tabular}{|l|ccc|}
\hline & \multicolumn{4}{|c|}{ Quarters after shock } \\
Response of: & 4 & 8 & 12 \\
\hline Capital & & & \\
Reduced Form & -0.0180 & -0.0540 & -0.0960 \\
VECM & -0.0090 & -0.0320 & -0.0670 \\
Investment & & & \\
Reduced Form & -0.3219 & -0.5307 & -0.5998 \\
VECM & -0.1825 & -0.3673 & -0.5084 \\
\hline
\end{tabular}


Chart 2: Capital impulse responses

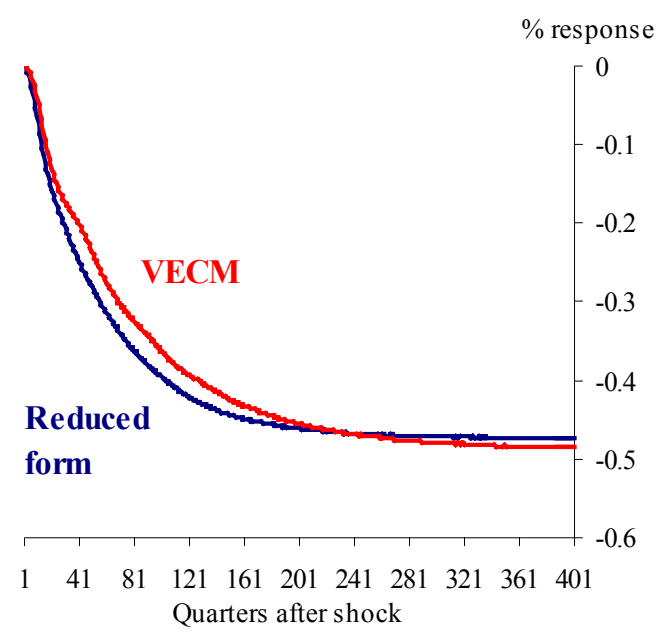

Chart 3: Investment impulse responses

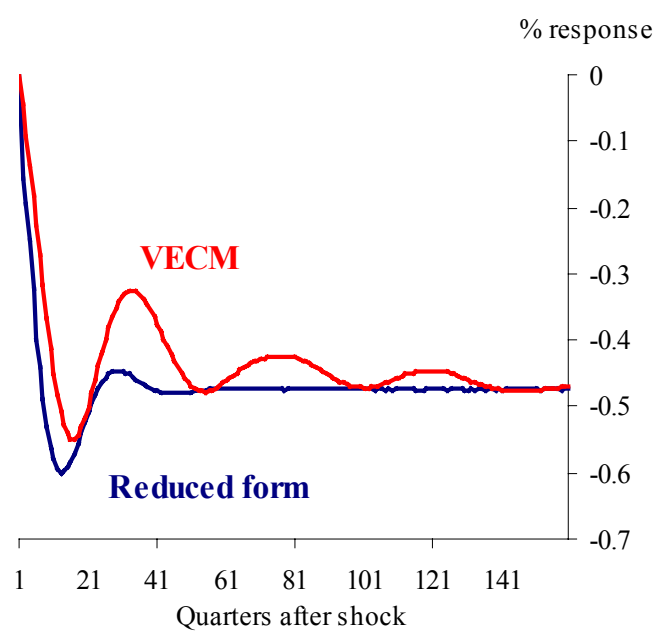

Chart 3 shows impulse responses for investment. These converge to the long-run rather more quickly than the capital stock, but near-complete convergence is still protracted. Investment over-shoots in both models. In principle there is no special reason why the two should give different answers, but as a matter of algebra, the reduced form is quicker partly because the long-run is defined directly in terms of investment.

\section{Monte Carlo simulations}

We are advocating system estimation. But this may come at the expense of low power or incorrectly sized test statistics. To investigate this, we carried out a Monte Carlo exercise, maintaining the restricted structure in the VECM. ${ }^{22}$ As a priori nothing rules out the possibility that both cointegrating vectors enter the investment ECM, we conducted three experiments. The first (Method 1) is to estimate by OLS a single equation embodying both CVs (equation (10)); the second (Method 2), the single reduced-form CV, again in an OLS regression; the third (Method 3), the correctly specified VECM, estimated by the Johansen method.

The parameters are from the parsimonious SUR system (Table A5), although we replace the capital ECM with the capital accumulation identity, where depreciation is stochastic, calibrating the normal additive error on $\delta$ to match the variance of capital stock growth. The other shocks were calibrated at the estimated variances. Results are based on 10,000 repetitions.

\footnotetext{
${ }^{22}$ In general we need to ensure that the model is estimated consistently under both the null and the alternative, and in non-stationary environments this may not always be true. But here we maintain the reduced rank hypothesis throughout, so this is not an issue.
} 
In Table 10 the first column reports the proportions with which the true hypothesis that the FOC is significant in a dynamic OLS regression; the power of the test. For a notional size of $5 \%$, it is $80.1 \%$. But the striking result is that the regression fails to reject the true hypothesis that the CAI should be excluded in the majority of cases. That is, the actual size of the test is much greater than the notional, and inference would be profoundly misleading. By contrast, the reduced form approach is highly robust, with a power of $93.1 \%$ at a notional size of 5\%. The VECM is also oversized on the set of long-run overidentifying restrictions (OIR), just over $50 \%$ at the notional $5 \%$ significance level. But conditional on these restrictions being accepted, the size of the test on the (true) hypothesis that the CAI should be excluded from the investment ECM is very small at just $0.1 \%$. Thus single equation techniques will lead one to falsely include the CAI in the estimated investment equation in the majority of cases, but this is much less likely to happen in a system context. Indeed, it will almost never occur. However, the true overidentifying restrictions will be falsely rejected roughly half the time (at a notional size of $5 \%$ ).

Table 10: Monte Carlo results

\begin{tabular}{|c|c|c|c|c|c|c|}
\hline \multirow{3}{*}{ Significance level } & \multicolumn{2}{|l|}{ Method 1} & \multirow{3}{*}{$\begin{array}{c}\text { Method } 2 \\
\text { RF } \\
\text { significant }\end{array}$} & \multicolumn{3}{|c|}{ Method 3} \\
\hline & $\begin{array}{c}\text { FOC } \\
\text { significant }\end{array}$ & $\begin{array}{c}\text { CAI } \\
\text { significant }\end{array}$ & & $\begin{array}{c}\text { OIR } \\
\text { rejected }\end{array}$ & $\begin{array}{l}\text { CAI significant, } \\
\text { conditional on } \\
\text { OIR accepted }\end{array}$ & $\begin{array}{l}\text { CAI WE and } \\
\text { OIR jointly } \\
\text { rejected }\end{array}$ \\
\hline & power & size & & size & size & size \\
\hline $10 \%$ & 89.68 & 79.99 & 97.01 & 62.40 & 0.00 & 52.14 \\
\hline $5 \%$ & 80.13 & 69.57 & 93.05 & 51.51 & 0.08 & 40.96 \\
\hline \multicolumn{7}{|c|}{ Estimated elasticity of substitution $($ actual $=0.487)$} \\
\hline Mean & 0.441 & & 0.452 & 0.708 & & \\
\hline Median & 0.438 & & 0.445 & 0.488 & & \\
\hline 5th Percentile & 0.174 & & 0.183 & 0.410 & & \\
\hline 95th Percentile & 0.651 & & 0.650 & 0.588 & & \\
\hline
\end{tabular}

The other question of interest is the estimate of the elasticity of substitution, $\sigma$. The table gives the mean and median estimates. The distributions are highly skewed, and the VECM mean is substantially biased upwards, but the median estimate is very close to the true value (0.49). The $95 \%$ confidence interval is also reported, and it is clear that the VECM will estimate the parameter with far more precision than the other methods. 
Finally, we bootstrapped the residuals to avoid making possibly incorrect distributional assumptions. We drew 6 period blocks to capture lumpiness in the depreciation series. The main difference to the Monte Carlo results is that the simulations now reveal a much reduced skew.

Table 11: Bootstrapped results

\begin{tabular}{|c|c|c|c|c|c|c|}
\hline & Method 1 & & Method 2 & Method 3 & & \\
\hline \multirow[t]{2}{*}{ Significance level } & \multirow{2}{*}{$\begin{array}{c}\text { FOC } \\
\text { significant } \\
\text { power }\end{array}$} & \multirow{2}{*}{$\begin{array}{c}\text { CAI } \\
\text { significant } \\
\text { size }\end{array}$} & \multirow{2}{*}{$\begin{array}{c}\mathrm{RF} \\
\text { significant } \\
\text { power }\end{array}$} & \multirow{2}{*}{$\begin{array}{c}\text { OIR } \\
\text { rejected } \\
\text { size }\end{array}$} & \multirow{2}{*}{$\begin{array}{l}\text { CAI significant, } \\
\text { conditional on } \\
\text { OIR accepted } \\
\text { size }\end{array}$} & \multirow{2}{*}{$\begin{array}{l}\text { CAI WE and } \\
\text { OIR jointly } \\
\text { rejected } \\
\text { size }\end{array}$} \\
\hline & & & & & & \\
\hline $10 \%$ & 92.29 & 85.08 & 98.77 & 63.77 & 0.17 & 53.61 \\
\hline $5 \%$ & 85.12 & 75.98 & 96.90 & 52.99 & 0.09 & 42.97 \\
\hline \multicolumn{7}{|c|}{ Estimated elasticity of substitution (actual $=0.487$ ) } \\
\hline Mean & 0.421 & & 0.458 & 0.445 & & \\
\hline Median & 0.457 & & 0.459 & 0.487 & & \\
\hline 5th Percentile & 0.301 & & 0.291 & 0.430 & & \\
\hline 95th Percentile & 0.589 & & 0.620 & 0.554 & & \\
\hline
\end{tabular}

\section{Conclusions}

Economic theory tells us that output, the capital stock and the user cost of capital are cointegrated. But from the capital accumulation identity, it also follows that the capital stock and investment share a long-run relationship. This has been used to justify the estimation of long-run investment, rather than capital stock, equations. Econometrically, the dynamic structure suggests a multicointegrating framework should exist, in which separate cointegrating relationships are identifiable. This turns out to be the case for UK business sector investment. A new investment equation is estimated, exploiting an internally constructed measure of the capital stock, and a long series for the weighted cost of capital. A CES production function is assumed, and a well-determined estimate of the elasticity of substitution is obtained by a variety of measures. The robust result is that the elasticity of substitution is significantly different from unity (the Cobb-Douglas case), at about 0.5 . Over-identifying restrictions on the long-run relationship are all accepted. Although the key long-run parameter (the elasticity of substitution) is highly robust to alternative specifications, single-equation investment relationships may obscure the dynamics. Thus we finally conclude that if we are interested only in knowing the elasticity of substitution, estimation using an OLS long-run investment relationship will return an unbiased 
estimate, although the Monte Carlo results show that that the VECM is considerably more accurate. In a macroeconometric modelling context, however, we may prefer to model investment via the long-run capital stock relationship, with the capital accumulation identity as a separate relationship. 


\section{References}

Bakhshi, $\mathbf{H}$ and Thompson, $\mathbf{J}$ (2002), 'Explaining trends in UK business investment', Bank of England Quarterly Bulletin, Spring.

Bean, C (1981), 'An econometric model of manufacturing investment in the UK', Economic Journal, March.

Brealey, $\mathbf{R}$ and Myers, $\mathbf{S}$ (2000), 'Principles of corporate finance', $6^{\text {th }}$ edition, Irwin McGraw-Hill.

Carruth, A, A Dickerson and A Henley (2000), 'Econometric modelling of UK aggregate investment: the role of profits and uncertainty', Manchester School 68, pages $276-300$.

Cheung, Y and K Lai (1993), 'Finite sample sizes of Johansen likelihood ratio tests for cointegration' Oxford Bulletin of Economics and Statistics 55 pp 313-328.

Chirinko, R, Fazzari, S and Meyer, A (2002), 'That elusive elasticity: a long-panel approach to estimating the price sensitivity of business capital', unpublished.

Cuthbertson, K and D Gasparro (1995), 'Fixed investment decisions in UK manufacturing: the importance of Tobin's Q, output and debt', European Economic Review, 39, pages 919-941.

Davidson, J (1994), 'Identifying cointegrating regressions by the rank condition', Oxford Bulletin of Economics and Statistics, 56, pp103-108.

Davidson, J (1998), 'Structural relations, cointegration and identification: some simple results and their application', Journal of Econometrics, 87, pp 87-113.

Engsted, T and N Haldrup (1999), 'Multicointegration and stock-flow models' Oxford Bulletin of Economics and Statistics 61 pp. 237-254.

Flemming, J, Price, L and Byers, S (1976), 'The cost of capital, finance, and investment', Bank of England Quarterly Bulletin, June.

Granger, C and T-H Lee (1991), 'Multicointegration', in R F Engle and C W J Granger Long-Run Economic Relationships (Oxford: OUP)

Greenslade, J V, Hall, S G and Henry, S G B (2002), 'On the identification of cointegrated systems in small samples: a modelling strategy with an application to UK wages and prices', Journal of Economic Dynamics and Control 26, pp 1517-37.

Hendry, D F and Juselius, K (2000), Explaining Cointegration Analysis: Part II unpublished.

Johansen, S (1995), Likelihood-Based Inference in Cointegrating Vector Autoregressive Models (Cambridge: CUP).

Larsen, J, Neiss, $\mathbf{K}$ and Shortall, $\mathbf{F}$ (2002), 'Factor utilisation and productivity estimates for the United Kingdom', Bank of England Working Paper 162.

Maddala, G S and I-M Kim (1998), Unit Roots, Cointegration and Structural Change (Cambridge: CUP).

Mayes, D and Young, G (1993), 'Industrial investment and economic policy', NIESR discussion paper No. 56.

NIESR (2002), 'World Model Manuals’, NIESR, LONDON, mimeo. 
Oliner, S, G Rudebusch and D Sichel (1995), 'New and old models of business investment: a comparison of forecasting perfomance' Journal of Money, Credit and Banking 27, pages 806-826.

Oulton, N (2001), 'Measuring capital services in the United Kingdom' Bank of England Quarterly Bulletin, 41 (Autumn), 295-309.

Oulton $\mathbf{N}$ and Srinivasan S (2002), 'Capital stocks, capital services, and depreciation: an integrated framework', Bank of England working paper, forthcoming.

Price, S (1995), 'Aggregate uncertainty, capacity utilisation and manufacturing investment', Applied Economics, 27, pp 147-154. 


\section{Data Appendix}

Business investment (I) and GDP (Y) are readily available from the Office for National Statistics (ONS) National Accounts data, with quarterly backruns to 1965 and 1955 respectively. The ONS capital stock and (implied) depreciation series exhibit worrying properties, however. Some of the issues are described in Oulton (2001). As such we also use a capital stock (and depreciation) series that has been constructed in-house following Oulton and Srinivasan (2002). ${ }^{23}$

The other key variable is the real user cost of capital (RCC). The full Hall-Jorgensen $\mathrm{RCC}$ is defined as:

$$
R C C=\frac{P_{K}}{P_{Y}}\left(c+\delta-E \frac{\dot{P_{K}}}{\dot{P}_{Y}}\right) \frac{1-P V I C}{1-\text { corptax }}
$$

where

$\begin{array}{lll}\mathrm{c} & \text { denotes } & \text { Real cost of finance } \\ \mathrm{P}_{\mathrm{k}} & \text { denotes } & \text { The price of capital goods (the IBUS deflator) } \\ \mathrm{P}_{\mathrm{y}} & \text { denotes } & \text { The price of all goods (the GDP deflator) } \\ \mathrm{PVIC} & \text { denotes } & \text { Present value of investment allowances } \\ \text { corptax } & \text { denotes } & \text { Corporation tax rate }\end{array}$

The price variables are available from National Accounts data, as is the effective corporation tax rate. PVIC is based on Bank calculations, following Mayes and Young (1993). The expected relative price inflation term is an unobserved variable, assumed to be zero. In unpublished work excluding this term improved the fit of singly-estimated investment equations. But we also experimented using a variety of assumptions including ARMA forecasts, filtered ex-post expectations and backwardlooking averages.

A more problematic issue is construction of a 'real cost of finance' variable. From 1982 Q1, a weighted average cost of capital (WACC) can be calculated, following Brealey and Myers (2000). But wanting to conduct estimation prior to 1982, previous work $^{24}$ has used an alternative cost of finance described in Flemming et al (1976). Essentially this measure is the ratio of current earnings to the financial valuation of companies. While in principle measuring a similar concept, over the same sample the Flemming measure is more volatile than WACC (see Chart A1) and the correlation is not strong ( 0.48 over the whole sample).

\footnotetext{
${ }^{23}$ We have assumed that the asset split of business investment is the same as whole-economy investment, and are grateful to Jamie Thompson for his help in constructing the series.

${ }^{24}$ See Bakhshi and Thompson (2002).
} 


\section{Chart A1: WACC and Fleming cost of finance}

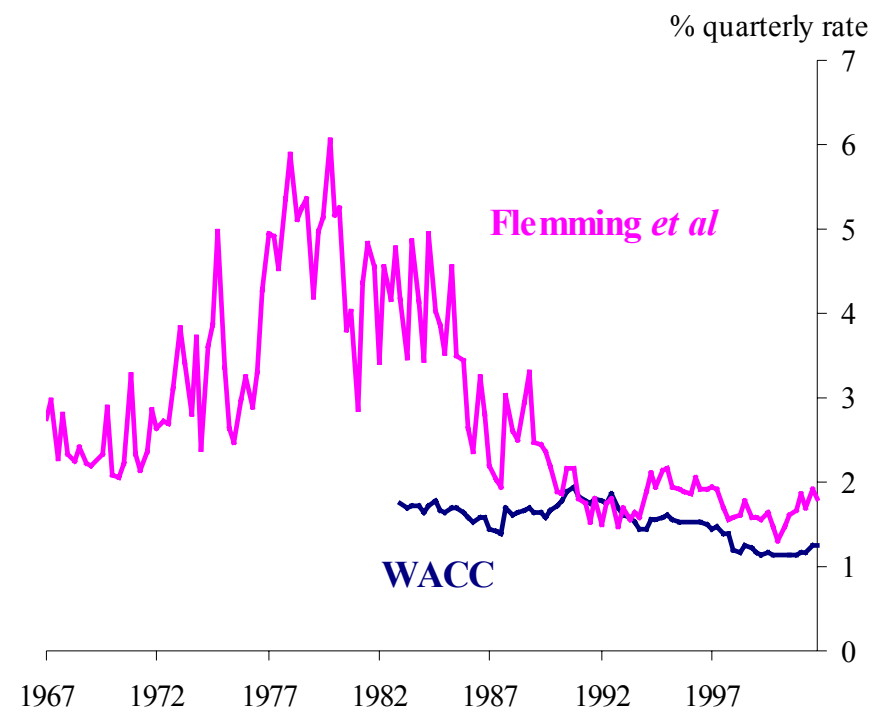

As an alternative we decided to construct a back series for WACC to 1970. WACC is calculated as the weighted average of the cost of debt finance $\left(\mathrm{R}^{\mathrm{D}}\right)$ and the cost of equity finance $\left(\mathrm{R}^{\mathrm{E}}\right)$ :

$W A C C_{t}=\lambda R_{t}^{D}+(1-\lambda) R_{t}^{E}$

The weight $(\lambda)$ is taken from company balance sheet data on the relative use of debt and equity finance: a weight of $15 \%$ is placed on debt, and $85 \%$ on equity. The real cost of debt finance is calculated as the risk-free real interest rate plus a measure of spreads, while the real cost of equity finance is calculated using a simple dividend discount model. Using these calculations, the cost of equity finance is readily available back to 1965, but the cost of debt finance only from 1982 (Chart A2). Thus to construct a WACC we need to backcast the cost of debt finance.

\section{Chart A2: WACC components}

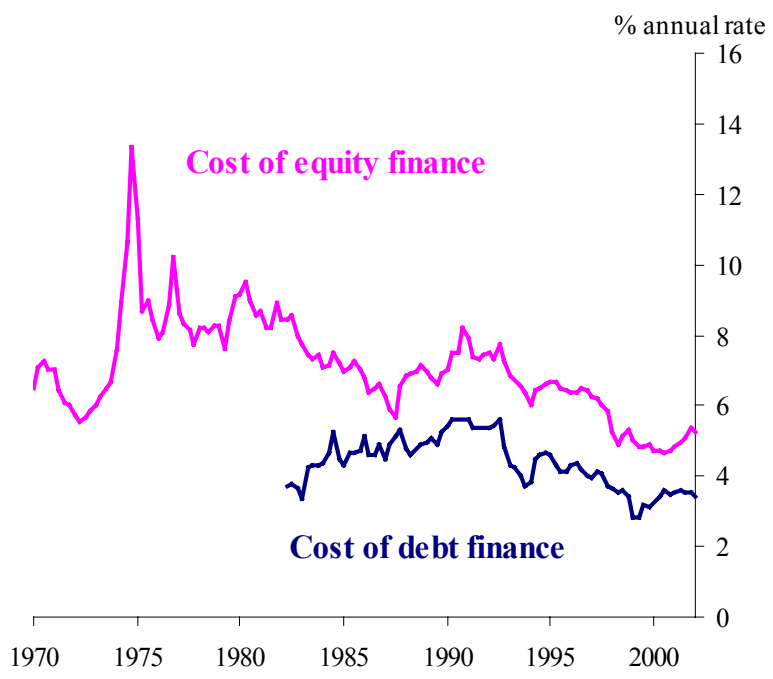


We constructed three different models to backcast the cost of debt finance using macro variables e.g. GDP, base rates, and inflation. Two of the three models included leads of the dependent variable (DV). The first model estimated the real risk-free rate and the spreads measure separately, including leading DVs (a "bottom-up" approach); the second estimated the cost of debt finance directly including leading DVs (a "topdown" approach); and the third was a "simple" equation for $\mathrm{R}^{\mathrm{D}}$ with no DVs included. The three different models produced very different backcasts for the cost of debt finance, shown in Chart A3. However, given the small weight of debt finance, the resulting backcast WACC series were almost indistinguishable (Chart A4). Given this, we picked the simple approach, due to concerns about the stability of the models including leading DVs.

\section{Chart A3: Backcast cost of debt \\ finance}

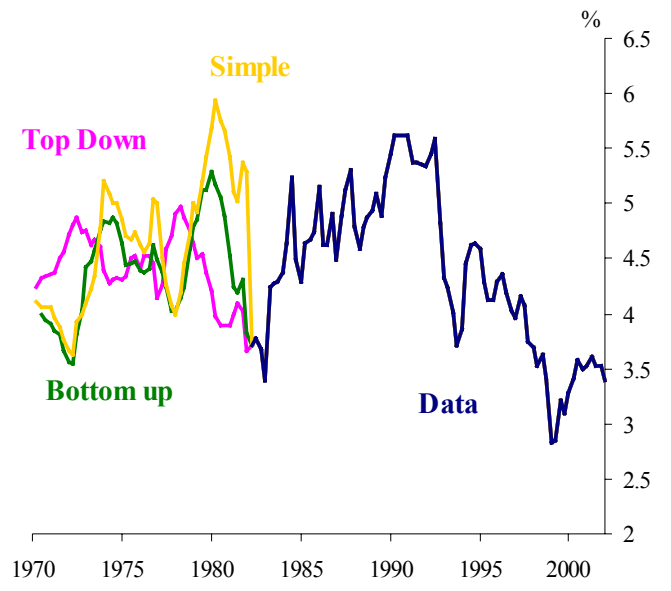

\section{Chart A4: Backcast WACC}

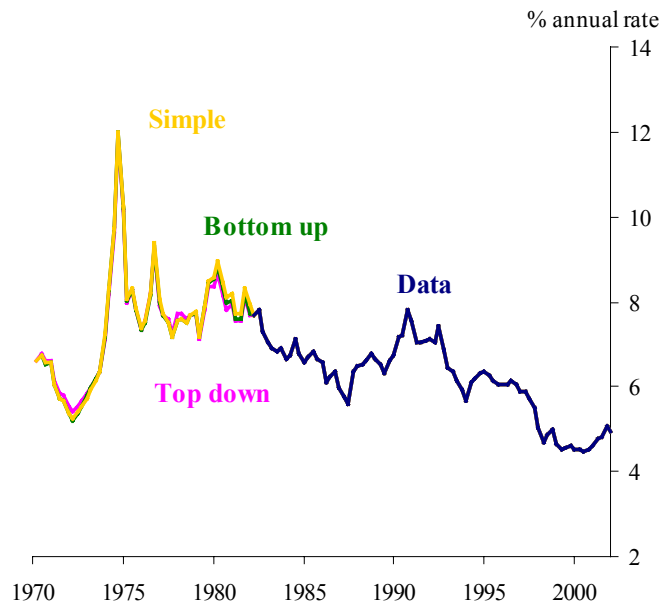

Having constructed our cost of finance term, we now have our four endogenous variables. ${ }^{25}$ Logged series are shown below in Charts A5 to A8. Unit root tests for all four variables are shown in tables A1 and A2. ${ }^{26}$ The tests indicate that all variables are i(1) at standard significance levels.

\footnotetext{
${ }^{25}$ All data are consistent with the 2002 Blue Book.

${ }^{26}$ For ADF tests, we included as many lagged differences in the auxiliary regressions as were significant.
} 
Chart A5: Investment (i)

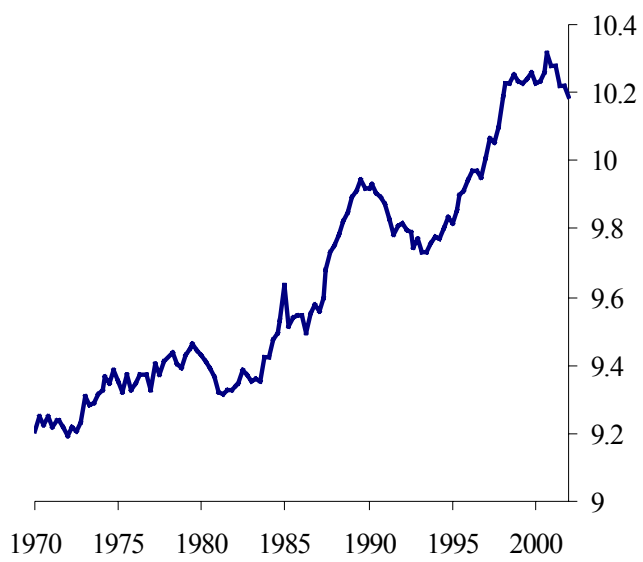

Chart A7: Real user cost of capital (r)

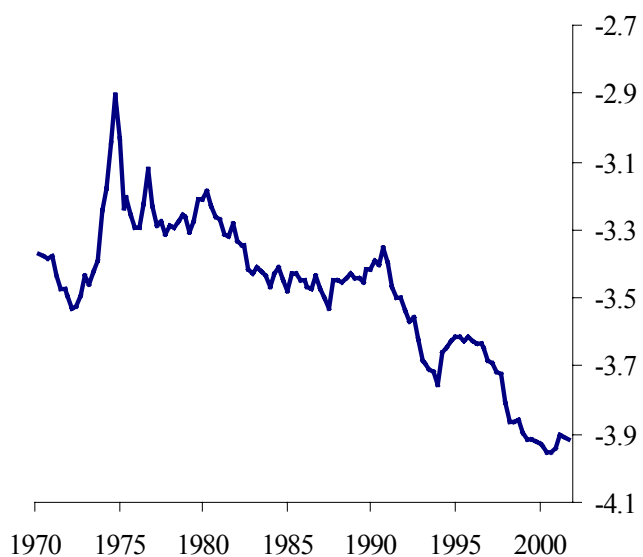

Table A1: ADF tests

\begin{tabular}{|l|c|c|}
\hline Variable & Level & First difference \\
\hline $\mathrm{i}$ & -0.734 & $-3.569^{* * *}$ \\
$\mathrm{k}$ & -0.179 & $-2.666^{*}$ \\
$\mathrm{r}$ & -0.558 & $-5.737^{* * *}$ \\
$\mathrm{y}$ & 0.029 & $-4.786^{* * *}$ \\
\hline \hline
\end{tabular}

$*(* *, * *)$ indicates significance at the $10 \%(5 \%, 1 \%)$ significance level

Table A2: KPSS and Phillips-Perron tests

\begin{tabular}{|l|c|c||}
\hline Variable & $\begin{array}{c}\text { KPSS } \\
\mathrm{H}_{0}=\mathrm{I}(0)\end{array}$ & $\begin{array}{c}\text { Phillips-Perron } \\
\mathrm{H}_{0}=\mathrm{I}(1)\end{array}$ \\
\hline $\mathrm{i}$ & $2.270 * * *$ & -0.491 \\
$\mathrm{k}$ & $2.490 * * *$ & -0.364 \\
$\mathrm{r}$ & $1.964 * * *$ & -0.623 \\
$\mathrm{y}$ & $2.465 * * *$ & -0.281 \\
\hline
\end{tabular}

$*(* *, * * *)$ indicates rejection of null at the $10 \%(5 \%, 1 \%)$ significance level
Chart A6: Capital stock (k)

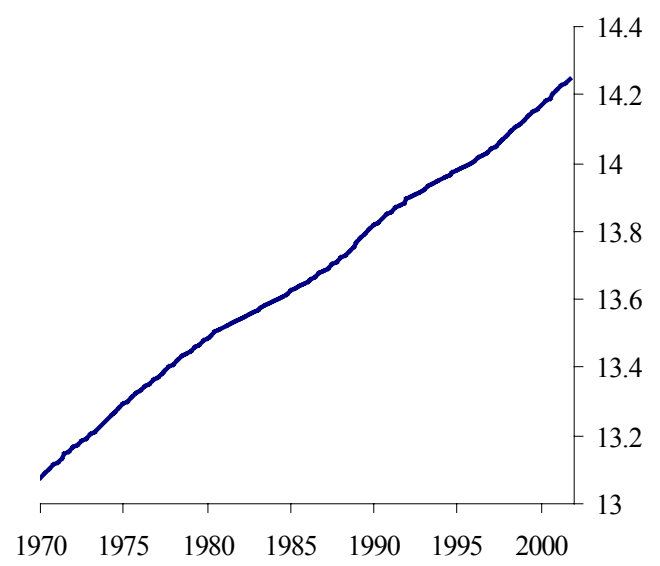

Chart A8: GDP (y)

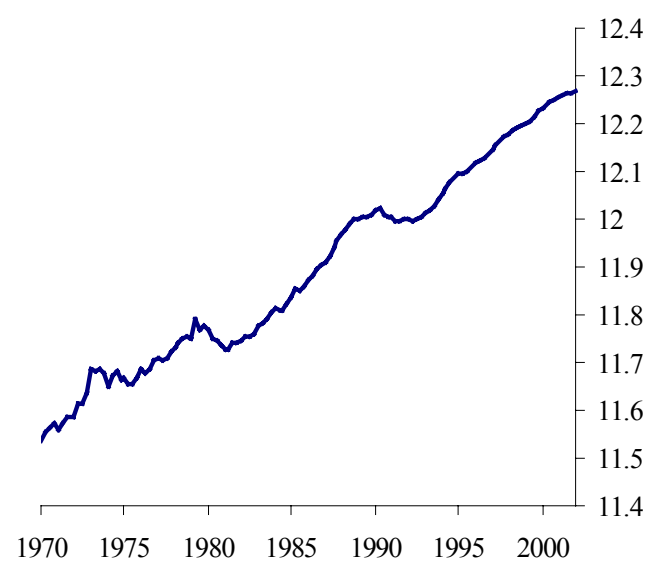




\section{Annex 1: Baseline single equation results}

Variables in single equation estimation are as listed in the main text and the Data Appendix, namely:

$\begin{array}{ll}\text { I } & \text { Business investment } \\ \text { K } & \text { Capital stock } \\ \text { Y } & \text { Gross Domestic Product } \\ \text { R } & \text { Real user cost of capital } \\ \text { FKU } & \text { Capital utilisation (taken from Larsen J, Neiss K and Shortall F (2002)) } \\ \text { D85_1 } & \text { Dummy variable for 1985 Q1 (tax allowance change) }\end{array}$

All estimation was carried out over the full data sample (1970 Q2 - 2001 Q4), adjusted for lags. FKU is an 'integral control variable', referred to in the main body of the text; (unreported) results were similar with other measures, eg the CBI capacity utilisation balance. A baseline least squares equation is shown in Equation A1, estimated using a 'general to specific' approach with four lags of all variables. It differs in dynamic detail from Table 7 in the main text, for comparability with Bakhshi and Thompson (2001).

Equation A1: Single equation estimates with investment in long-run

Dependent Variable: $\Delta \mathrm{i}$

Sample(adjusted): 1971:2 2002:1

\begin{tabular}{crrrr}
\hline \hline & Coefficient & Std. Error & t-Statistic & Prob. \\
\hline \hline Constant & -1.169883 & 0.245649 & -4.762411 & 0.0000 \\
$\Delta \mathrm{i}(-4)$ & 0.159909 & 0.079877 & 2.001936 & 0.0476 \\
FKU(-1) & 0.652244 & 0.188109 & 3.467378 & 0.0007 \\
1985:1 dummy & 0.105947 & 0.028837 & 3.674024 & 0.0004 \\
1985:1 dummy lagged & -0.126417 & 0.029031 & -4.354503 & 0.0000 \\
i(-1)-y(-1) & -0.130131 & 0.028800 & -4.518517 & 0.0000 \\
r(-1)* & $\mathbf{0 . 5 1 1 1 3 2}$ & 0.091144 & 5.607972 & 0.0000 \\
\hline \hline R-squared & 0.356953 & Mean dependent var & 0.007787 \\
Adjusted R-squared & 0.323976 & S.D. dependent var & 0.034801 \\
S.E. of regression & 0.028614 & Akaike info criterion & -4.215050 \\
Sum squared resid & 0.095795 & Schwarz criterion & -4.055841 \\
Log likelihood & 268.3331 & Durbin-Watson stat & 2.084497 \\
\hline * Long-run value. & \multicolumn{4}{l}{}
\end{tabular}

The estimated elasticity of substitution is 0.51 , significantly different from unity (as would be implied under Cobb-Douglas technology). The equation is well specified in terms of the usual residual test criteria (normality, homoscedasticity, serial correlation and ARCH test). In addition we estimated a DOLS regression with two leads to compare the estimated elasticity of substitution in the long-run relationship. Results are shown below. The DOLS estimate of 0.43 is a little lower than that in the baseline equation above (0.51), but our baseline estimate is not significantly difference from the lower DOLS estimate.

Equation A2: DOLS equation estimates (two leads): investment in long-run

Dependent Variable: i-y

Sample(adjusted): 1971:1 2001:2

\begin{tabular}{crrrr}
\hline \hline & Coefficient & Std. Error & t-Statistic & Prob. \\
\hline \hline Constant & -6.952356 & 0.555914 & -12.50617 & 0.0000 \\
$\mathbf{r}$ & $\mathbf{- 0 . 4 3 4 9 7 9}$ & 0.036132 & -12.03861 & 0.0000
\end{tabular}




\begin{tabular}{crrrr}
$\Delta \mathrm{r}(-1)$ & -0.055584 & 0.173045 & -0.321212 & 0.7487 \\
$\Delta \mathrm{r}(-2)$ & 0.055279 & 0.171561 & 0.322210 & 0.7479 \\
$\Delta \mathrm{r}(+1)$ & -0.414721 & 0.167442 & -2.476803 & 0.0148 \\
$\Delta \mathrm{r}(+2)$ & -0.515120 & 0.166413 & -3.095434 & 0.0025 \\
$\Delta(\mathrm{i}(-1)-\mathrm{y}(-1))$ & 0.407197 & 0.242330 & 1.680340 & 0.0957 \\
$\Delta(\mathrm{i}(-2)-\mathrm{y}(-2))$ & 0.285502 & 0.239358 & 1.192782 & 0.2355 \\
FKU(-1) & 3.182071 & 0.552722 & 5.757092 & 0.0000 \\
$1985: 1$ dummy & 0.104843 & 0.083281 & 1.258903 & 0.2107 \\
$1985: 1$ dummy lagged & -0.088384 & 0.085307 & -1.036080 & 0.3024 \\
\hline \hline R-squared & 0.676166 & Mean dependent var & -2.249935 \\
Adjusted R-squared & 0.646991 & S.D. dependent var & 0.136100 \\
S.E. of regression & 0.080863 & Akaike info criterion & -2.106277 \\
Sum squared resid & 0.725815 & Schwarz criterion & -1.853455 \\
Log likelihood & 139.4829 & Durbin-Watson stat & 0.334110 \\
\hline \hline
\end{tabular}

We also replicated the single equation results using the capital stock (KS) rather than investment in the long-run. The corresponding results are shown below.

Equation A3: Single equation estimates with capital in long-run

Dependent Variable: $\Delta \mathrm{i}$

Sample(adjusted): 1971:2 2002:1

\begin{tabular}{crrrr}
\hline \hline & Coefficient & Std. Error & t-Statistic & Prob. \\
\hline \hline Constant & 0.056827 & 0.047587 & 1.194184 & 0.2348 \\
$\Delta \mathrm{i}(-3)$ & 0.213625 & 0.079322 & 2.693140 & 0.0081 \\
$\Delta \mathrm{i}(-4)$ & 0.251448 & 0.079833 & 3.149675 & 0.0021 \\
$\Delta \mathrm{k}(-1)$ & -5.763616 & 1.625906 & -3.544865 & 0.0006 \\
$1985: 1$ dummy & 0.086419 & 0.029767 & 2.903161 & 0.0044 \\
$1985: 1$ dummy lagged & -0.142597 & 0.029679 & -4.804624 & 0.0000 \\
$(\mathrm{k}(-1)-\mathrm{y}(-1))$ & -0.095662 & 0.035467 & -2.697200 & 0.0080 \\
r(-1)* & $\mathbf{0 . 5 1 0 9 8 8}$ & 0.131373 & 3.889587 & 0.0002 \\
\hline \hline R-squared & 0.328656 & Mean dependent var & 0.007787 \\
Adjusted R-squared & 0.288143 & S.D. dependent var & 0.034801 \\
S.E. of regression & 0.029362 & Akaike info criterion & -4.155857 \\
Sum squared resid & 0.100010 & Schwarz criterion & -3.973903 \\
Log likelihood & 265.6631 & Durbin-Watson stat & 2.014129 \\
\hline * Long-run value. & \multicolumn{4}{l}{} \\
\end{tabular}

Once again the estimated elasticity of substitution is close to 0.5. And yet again DOLS estimation (see below) suggested a slightly smaller coefficient, but not radically different.

Equation A4: DOLS equation estimates for capital (two leads)

Dependent Variable: k-y

Sample(adjusted): 1971:1 2001:2

\begin{tabular}{crrrr}
\hline \hline & Coefficient & Std. Error & t-Statistic & Prob. \\
\hline \hline Constant & 0.287322 & 0.122623 & 2.343128 & 0.0209 \\
$\mathbf{r}$ & $\mathbf{- 0 . 4 2 5 1 9 7}$ & 0.035003 & -12.14754 & 0.0000 \\
$\Delta \mathrm{r}(-1)$ & 0.028893 & 0.159425 & 0.181232 & 0.8565 \\
$\Delta \mathrm{r}(-2)$ & 0.048398 & 0.157955 & 0.306405 & 0.7599 \\
$\Delta \mathrm{r}(+1)$ & -0.350058 & 0.157729 & -2.219371 & 0.0285 \\
$\Delta \mathrm{r}(+2)$ & -0.517238 & 0.158090 & -3.271786 & 0.0014 \\
$\Delta(\mathrm{k}(-1)-\mathrm{y}(-1))$ & 1.239275 & 0.700934 & 1.768033 & 0.0798 \\
$\Delta(\mathrm{k}(-2)-\mathrm{y}(-2))$ & 0.924749 & 0.695961 & 1.328737 & 0.1866 \\
$1985: 1$ dummy & 0.034583 & 0.078278 & 0.441802 & 0.6595 \\
$1985: 1$ dummy lagged & 0.034922 & 0.078248 & 0.446305 & 0.6562 \\
\hline \hline
\end{tabular}


R-squared

Adjusted R-squared

S.E. of regression

Sum squared resid

Log likelihood
0.609103 Mean dependent var

0.577692 S.D. dependent var

0.077125 Akaike info criterion

0.666205 Schwarz criterion

144.7104 Durbin-Watson stat
1.778145

0.118681

$-2.208367$

$-1.978529$

0.133597 


\section{Annex 2: estimated system}

The system below is the full version of the summary shown in Table 3 .

Table A3: Full system results from Johansen estimation

\begin{tabular}{|c|c|c|}
\hline $\begin{array}{l}\text { Vector Error Correction } \\
\text { Sample(adjusted): } 197 \\
\text { Included observations: } \\
\text { Standard errors in ( ) a }\end{array}$ & $\begin{array}{l}\text { mates } \\
001: 4 \\
\text { after adjusti } \\
\text { tatistics in [ }\end{array}$ & ndpoints \\
\hline LR test for binding rest & ns $($ rank $=2$ & \\
\hline Chi-square(6) & 4.081410 & \\
\hline Probability & 0.665660 & \\
\hline Cointegrating Eq: & $\begin{array}{c}\text { CointEq1 } \\
\text { CAI }\end{array}$ & $\begin{array}{c}\text { CointEq2 } \\
\text { FOC }\end{array}$ \\
\hline $\mathrm{r}(-1)$ & 0.000000 & $\begin{array}{r}-0.487096 \\
(0.04229) \\
{[-11.5184]}\end{array}$ \\
\hline $\mathrm{i}(-1)$ & -1.000000 & 0.000000 \\
\hline $\mathrm{y}(-1)$ & 0.000000 & 1.000000 \\
\hline $\mathrm{k}(-1)$ & 1.000000 & -1.000000 \\
\hline $\mathrm{C}$ & -4.032444 & 0.091444 \\
\hline
\end{tabular}

\begin{tabular}{|c|c|c|c|c|}
\hline Error Correction: & $\Delta \mathrm{r}$ & $\Delta \mathrm{i}$ & $\Delta y$ & $\Delta \mathrm{k}$ \\
\hline CointEq1 loading & 0.952169 & 0.000000 & 0.000000 & -0.007275 \\
\hline CAI & [ 2.99763] & [ NA ] & [ NA ] & {$[-3.88294]$} \\
\hline CointEq 2 loading & 0.401817 & 0.067316 & 0.042108 & 0.000000 \\
\hline FOC & [ 4.07184] & [2.16511] & [ 2.40312] & [ NA ] \\
\hline \multirow[t]{2}{*}{$\Delta \mathrm{r}(-1)$} & 0.226944 & -0.094932 & -0.002288 & -0.001148 \\
\hline & [ 2.39367$]$ & {$[-1.11953]$} & {$[-0.09552]$} & {$[-0.72356]$} \\
\hline \multirow{2}{*}{$\Delta \mathrm{r}(-2)$} & -0.110199 & 0.001630 & -0.008236 & -0.000442 \\
\hline & {$[-1.21306]$} & [ 0.02007] & {$[-0.35893]$} & {$[-0.29040]$} \\
\hline \multirow{2}{*}{$\Delta \mathrm{r}(-3)$} & 0.156324 & 0.022960 & -0.048215 & 0.000665 \\
\hline & [ 1.78001$]$ & [ 0.29231$]$ & {$[-2.17346]$} & {$[0.45221]$} \\
\hline \multirow[t]{2}{*}{$\Delta \mathrm{r}(-4)$} & -0.025504 & -0.064456 & -0.011040 & -0.001333 \\
\hline & {$[-0.27864]$} & {$[-0.78736]$} & {$[-0.47749]$} & {$[-0.87015]$} \\
\hline \multirow[t]{2}{*}{$\Delta \mathrm{r}(-5)$} & -0.189192 & 0.068779 & 0.016333 & 0.001767 \\
\hline & {$[-2.21604]$} & {$[0.90075]$} & {$[0.75737]$} & [ 1.23688$]$ \\
\hline \multirow[t]{2}{*}{$\Delta \mathrm{r}(-6)$} & -0.061289 & -0.012704 & -0.026195 & -0.000243 \\
\hline & {$[-0.71308]$} & {$[-0.16527]$} & {$[-1.20656]$} & {$[-0.16919]$} \\
\hline \multirow[t]{2}{*}{$\Delta \mathrm{r}(-7)$} & -0.050634 & 0.042542 & -0.011742 & 0.001275 \\
\hline & {$[-0.58869]$} & {$[0.55302]$} & {$[-0.54046]$} & [ 0.88587$]$ \\
\hline \multirow[t]{2}{*}{$\Delta \mathrm{r}(-8)$} & 0.329762 & 0.036840 & 0.008203 & 0.000524 \\
\hline & [ 4.02817] & {$[0.50315]$} & {$[0.39670]$} & [ 0.38207$]$ \\
\hline \multirow[t]{2}{*}{$\Delta \mathrm{i}(-1)$} & 0.766695 & -0.125365 & 0.092538 & -0.006574 \\
\hline & [ 2.03765$]$ & {$[-0.37253]$} & {$[0.97365]$} & {$[-1.04381]$} \\
\hline \multirow[t]{2}{*}{$\Delta \mathrm{i}(-2)$} & 0.777583 & -0.099428 & 0.079507 & -0.004195 \\
\hline & [ 2.02446] & {$[-0.28943]$} & [ 0.81948$]$ & {$[-0.65261]$} \\
\hline \multirow[t]{2}{*}{$\Delta \mathrm{i}(-3)$} & 0.052655 & -0.114795 & 0.107372 & -0.004011 \\
\hline & {$[0.13803]$} & {$[-0.33645]$} & [ 1.11427$]$ & {$[-0.62817]$} \\
\hline \multirow[t]{2}{*}{$\Delta \mathrm{i}(-4)$} & 0.382264 & 0.215494 & -0.126779 & 0.001590 \\
\hline & [ 0.99879] & [ 0.62954$]$ & {$[-1.31139]$} & [ 0.24816$]$ \\
\hline
\end{tabular}




\begin{tabular}{|c|c|c|c|c|}
\hline \multirow[t]{2}{*}{$\Delta \mathrm{i}(-5)$} & 0.251271 & -0.037890 & -0.154780 & -0.007375 \\
\hline & [ 0.64121$]$ & {$[-0.10811]$} & {$[-1.56368]$} & {$[-1.12447]$} \\
\hline \multirow[t]{2}{*}{$\Delta \mathrm{i}(-6)$} & -0.532432 & -0.320801 & 0.061673 & -0.007069 \\
\hline & {$[-1.29999]$} & {$[-0.87576]$} & [ 0.59613$]$ & {$[-1.03121]$} \\
\hline \multirow[t]{2}{*}{$\Delta \mathrm{i}(-7)$} & 0.934136 & 0.005441 & 0.008720 & -0.000922 \\
\hline & [ 1.94228$]$ & [ 0.01265$]$ & {$[0.07178]$} & {$[-0.11455]$} \\
\hline \multirow[t]{2}{*}{$\Delta \mathrm{i}(-8)$} & 0.052139 & -0.067622 & 0.043296 & -0.001617 \\
\hline & [ 0.39995$]$ & {$[-0.57998]$} & [ 1.31484$]$ & {$[-0.74104]$} \\
\hline \multirow[t]{2}{*}{$\Delta \mathrm{y}(-1)$} & -1.063908 & 0.056689 & -0.127850 & 0.003898 \\
\hline & {$[-2.27477]$} & {$[0.13552]$} & {$[-1.08220]$} & {$[0.49791]$} \\
\hline \multirow[t]{2}{*}{$\Delta y(-2)$} & -0.343096 & 0.259335 & 0.087875 & 0.008229 \\
\hline & {$[-0.73208]$} & [ 0.61870] & {$[0.74230]$} & [ 1.04904] \\
\hline \multirow[t]{2}{*}{$\Delta y(-3)$} & -0.859075 & 0.296681 & 0.144272 & 0.006625 \\
\hline & {$[-1.93478]$} & {$[0.74708]$} & [ 1.28634$]$ & [ 0.89141$]$ \\
\hline \multirow[t]{2}{*}{$\Delta y(-4)$} & 0.217365 & 0.080207 & -0.229443 & 0.005826 \\
\hline & {$[0.47348]$} & [ 0.19534$]$ & {$[-1.97860]$} & {$[0.75825]$} \\
\hline \multirow[t]{2}{*}{$\Delta y(-5)$} & 0.669464 & 0.661368 & -0.027394 & 0.012399 \\
\hline & [ 1.50013$]$ & {$[1.65700]$} & {$[-0.24302]$} & [ 1.65998$]$ \\
\hline \multirow[t]{2}{*}{$\Delta y(-6)$} & 0.946097 & 0.219878 & 0.062847 & 0.003351 \\
\hline & [2.26016] & {$[0.58730]$} & [ 0.59437$]$ & [ 0.47830$]$ \\
\hline \multirow[t]{2}{*}{$\Delta y(-7)$} & 1.132815 & 0.039173 & -0.022904 & -0.000464 \\
\hline & [ 2.80966] & [ 0.10863$]$ & {$[-0.22489]$} & {$[-0.06869]$} \\
\hline \multirow[t]{2}{*}{$\Delta y(-8)$} & -0.076194 & -0.060149 & -0.195318 & -0.001289 \\
\hline & {$[-0.18658]$} & {$[-0.16468]$} & {$[-1.89347]$} & {$[-0.18853]$} \\
\hline \multirow[t]{2}{*}{$\Delta \mathrm{k}(-1)$} & 6.670670 & 2.434786 & -3.383969 & 0.869286 \\
\hline & {$[0.37062]$} & {$[0.15125]$} & {$[-0.74433]$} & [ 2.88557] \\
\hline \multirow[t]{2}{*}{$\Delta \mathrm{k}(-2)$} & 1.069177 & 2.347818 & -2.510422 & -0.093058 \\
\hline & [ 0.04465$]$ & [ 0.10964] & {$[-0.41509]$} & {$[-0.23221]$} \\
\hline \multirow[t]{2}{*}{$\Delta \mathrm{k}(-3)$} & 37.45416 & 3.489607 & -2.889120 & 0.067487 \\
\hline & [ 1.51353$]$ & [ 0.15767$]$ & {$[-0.46220]$} & [ 0.16294$]$ \\
\hline \multirow[t]{2}{*}{$\Delta \mathrm{k}(-4)$} & -32.24643 & -15.72479 & 13.49078 & -0.286942 \\
\hline & {$[-1.26730]$} & {$[-0.69097]$} & [ 2.09898] & {$[-0.67375]$} \\
\hline \multirow[t]{2}{*}{$\Delta \mathrm{k}(-5)$} & 18.49647 & 1.926763 & 2.813069 & 0.299220 \\
\hline & [ 0.69893$]$ & [0.08141] & [ 0.42082$]$ & [ 0.67553$]$ \\
\hline \multirow[t]{2}{*}{$\Delta \mathrm{k}(-6)$} & 31.46754 & 18.10585 & -9.977920 & 0.031719 \\
\hline & [ 1.18659$]$ & [ 0.76337] & {$[-1.48954]$} & [ 0.07146$]$ \\
\hline \multirow[t]{2}{*}{$\Delta \mathrm{k}(-7)$} & -52.99518 & -3.805771 & -0.080321 & -0.079318 \\
\hline & {$[-1.74333]$} & {$[-0.13998]$} & {$[-0.01046]$} & {$[-0.15589]$} \\
\hline$\Delta \mathrm{k}(-8)$ & 33.48509 & -13.15441 & 0.401224 & -0.252899 \\
\hline & [ 1.31428$]$ & {$[-0.57728]$} & [ 0.06234$]$ & {$[-0.59305]$} \\
\hline Constant & -0.423091 & 0.044621 & 0.025202 & 0.004086 \\
\hline & {$[-2.82300]$} & {$[0.33288]$} & {$[0.66572]$} & [ 1.62877$]$ \\
\hline 1985:1 dummy & -0.047661 & 0.091405 & 0.014515 & 0.001597 \\
\hline & {$[-1.13778]$} & {$[2.43975]$} & {$[1.37178]$} & [2.27805] \\
\hline 1985:1 dummy lagged & 0.072806 & -0.137998 & 0.000895 & -0.002461 \\
\hline & {$[1.85113]$} & {$[-3.92302]$} & {$[0.09005]$} & {$[-3.73768]$} \\
\hline R-squared & 0.631335 & 0.475100 & 0.473243 & 0.936711 \\
\hline Adj. R-squared & 0.467484 & 0.241812 & 0.239128 & 0.908582 \\
\hline Sum sq. resids & 0.095217 & 0.076166 & 0.006075 & $2.67 \mathrm{E}-05$ \\
\hline S.E. equation & 0.034286 & 0.030665 & 0.008660 & 0.000574 \\
\hline F-statistic & 3.853104 & 2.036533 & 2.021416 & 33.30117 \\
\hline Log likelihood & 252.7799 & 265.9513 & 415.1437 & 735.4112 \\
\hline Akaike AIC & -3.657287 & -3.880530 & -6.409215 & -11.83748 \\
\hline Schwarz SC & -2.788513 & -3.011756 & -5.540441 & -10.96870 \\
\hline Mean dependent & -0.003242 & 0.008487 & 0.005533 & 0.009067 \\
\hline S.D. dependent & 0.046984 & 0.035217 & 0.009929 & 0.001898 \\
\hline
\end{tabular}




\begin{tabular}{lr}
\hline \hline Determinant Residual Covariance & $3.25 \mathrm{E}-18$ \\
Log Likelihood & 1794.882 \\
Log Likelihood (d.f. adjusted) & 1706.112 \\
Akaike Information Criteria & -26.27308 \\
Schwarz Criteria & -22.61014 \\
\hline \hline
\end{tabular}

The residuals from the system are shown below.

\section{Chart A9: VECM residuals}
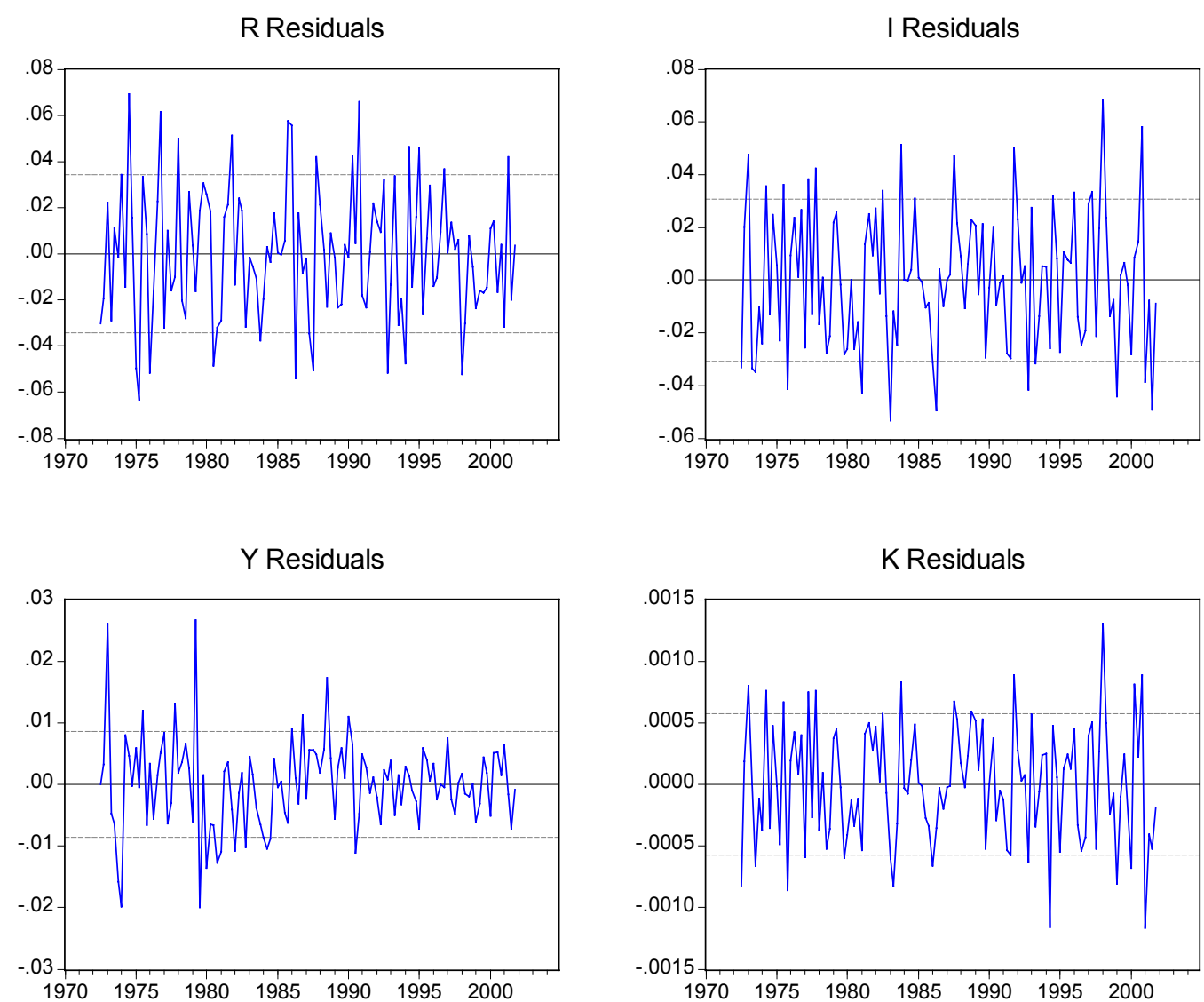

The system at the moment is very over-parameterised. As mentioned in the main text, we therefore tested down to a parsimonious form using SUR. Results for this, without imposing the weak exogeneity (WE) restrictions accepted under Johansen estimation, are shown below in Table A4.

Table A4: SUR estimates, not imposing WE Estimation Method: Seemingly Unrelated Regression Sample: 1972:1 2002:1

Coefficient $\quad$ Std. Error $\quad$ t-Statistic $\quad$ Prob.

$\begin{array}{crrrr}\Delta \text { r equation } & & & & \\ \text { FOC* } & \mathbf{0 . 3 8 2 9 0 7} & \mathbf{0 . 0 5 9 3 2 3} & \mathbf{6 . 4 5 4 5 7 2} & \mathbf{0 . 0 0 0 0} \\ \text { CAI* }^{*} & \mathbf{0 . 8 3 0 0 0 1} & \mathbf{0 . 1 7 4 8 5 0} & \mathbf{4 . 7 4 6 9 3 9} & \mathbf{0 . 0 0 0 0} \\ \Delta \mathrm{r}(-1) & 0.243153 & 0.067477 & 3.603475 & 0.0004 \\ \Delta \mathrm{r}(-2) & -0.133780 & 0.066185 & -2.021309 & 0.0439 \\ \Delta \mathrm{r}(-3) & 0.160364 & 0.066062 & 2.427462 & 0.0156 \\ \Delta \mathrm{r}(-5) & -0.162267 & 0.061812 & -2.625161 & 0.0090 \\ \Delta \mathrm{r}(-8) & 0.315781 & 0.064598 & 4.888375 & 0.0000\end{array}$




\begin{tabular}{|c|c|c|c|c|}
\hline$\Delta \mathrm{i}(-1)$ & 0.738964 & 0.199086 & 3.711781 & 0.0002 \\
\hline$\Delta \mathrm{i}(-2)$ & 0.744976 & 0.186712 & 3.989971 & 0.0001 \\
\hline$\Delta \mathrm{i}(-6)$ & -0.253838 & 0.112134 & -2.263702 & 0.0241 \\
\hline$\Delta \mathrm{i}(-7)$ & 0.790046 & 0.337004 & 2.344325 & 0.0195 \\
\hline$\Delta y(-1)$ & -0.835937 & 0.345385 & -2.420304 & 0.0159 \\
\hline$\Delta y(-3)$ & -0.660715 & 0.318570 & -2.074005 & 0.0387 \\
\hline$\Delta y(-5)$ & 0.547227 & 0.345288 & 1.584843 & 0.1137 \\
\hline$\Delta y(-6)$ & 0.911267 & 0.328870 & 2.770900 & 0.0058 \\
\hline$\Delta y(-7)$ & 1.251684 & 0.315997 & 3.961064 & 0.0001 \\
\hline$\Delta \mathrm{k}(-3)$ & 39.23613 & 9.508261 & 4.126531 & 0.0000 \\
\hline$\Delta \mathrm{k}(-4)$ & -13.14682 & 5.965400 & -2.203845 & 0.0281 \\
\hline$\Delta \mathrm{k}(-5)$ & 14.97934 & 6.172408 & 2.426822 & 0.0156 \\
\hline$\Delta \mathrm{k}(-7)$ & -31.04468 & 17.94314 & -1.730170 & 0.0843 \\
\hline$\Delta \mathrm{k}(-8)$ & 27.36244 & 17.35224 & 1.576883 & 0.1156 \\
\hline Constant & -0.365846 & 0.084403 & -4.334510 & 0.0000 \\
\hline 1985:1 dummy lagged & 0.070512 & 0.032300 & 2.183023 & 0.0296 \\
\hline R-squared & 0.598735 & Mean depenc & nt var & -0.003242 \\
\hline Adjusted R-squared & 0.505810 & S.D. depende & t var & 0.046984 \\
\hline S.E. of regression & 0.033029 & Sum squared & esid & 0.103637 \\
\hline Durbin-Watson stat & 2.087646 & & & \\
\hline$\Delta \mathbf{i}$ equation & & & & \\
\hline FOC* & 0.112620 & 0.035694 & 3.155126 & 0.0017 \\
\hline CAI* & 0.031590 & 0.032527 & 0.971174 & 0.3320 \\
\hline$\Delta \mathrm{i}(-7)$ & 0.299382 & 0.072270 & 4.142532 & 0.0000 \\
\hline$\Delta \mathrm{k}(-7)$ & -6.647218 & 1.611822 & -4.124040 & 0.0000 \\
\hline Constant & 0.065074 & 0.015084 & 4.314048 & 0.0000 \\
\hline 1985:1 dummy & 0.078012 & 0.028029 & 2.783254 & 0.0056 \\
\hline 1985:1 dummy lagged & -0.151325 & 0.027383 & -5.526266 & 0.0000 \\
\hline R-squared & 0.382091 & Mean depenc & nt var & 0.008007 \\
\hline Adjusted R-squared & 0.349570 & S.D. depende & t var & 0.035112 \\
\hline S.E. of regression & 0.028317 & Sum squared & & 0.091413 \\
\hline Durbin-Watson stat & 2.127822 & & & \\
\hline$\Delta y$ equation & & & & \\
\hline FOC* & 0.035241 & 0.012676 & 2.780112 & 0.0057 \\
\hline CAI* & -0.049691 & 0.041670 & -1.192490 & 0.2337 \\
\hline$\Delta \mathrm{r}(-3)$ & -0.054191 & 0.014702 & -3.686029 & 0.0003 \\
\hline$\Delta \mathrm{r}(-6)$ & -0.033178 & 0.015122 & -2.194000 & 0.0288 \\
\hline$\Delta \mathrm{i}(-1)$ & 0.072563 & 0.024791 & 2.926978 & 0.0036 \\
\hline$\Delta \mathrm{i}(-4)$ & -0.168958 & 0.051836 & -3.259496 & 0.0012 \\
\hline$\Delta \mathrm{i}(-5)$ & -0.128016 & 0.050025 & -2.559037 & 0.0108 \\
\hline$\Delta \mathrm{i}(-6)$ & 0.071179 & 0.021404 & 3.325505 & 0.0010 \\
\hline$\Delta \mathrm{i}(-8)$ & 0.055609 & 0.021949 & 2.533594 & 0.0116 \\
\hline$\Delta y(-3)$ & 0.141914 & 0.078034 & 1.818616 & 0.0697 \\
\hline$\Delta \mathrm{y}(-4)$ & -0.221450 & 0.078258 & -2.829728 & 0.0049 \\
\hline$\Delta y(-8)$ & -0.176656 & 0.072179 & -2.447480 & 0.0148 \\
\hline$\Delta \mathrm{k}(-1)$ & -5.034970 & 2.209140 & -2.279154 & 0.0232 \\
\hline$\Delta \mathrm{k}(-4)$ & 9.490053 & 2.676250 & 3.546026 & 0.0004 \\
\hline$\Delta \mathrm{k}(-6)$ & -8.694220 & 2.512138 & -3.460885 & 0.0006 \\
\hline Constant & 0.045849 & 0.019834 & 2.311624 & 0.0213 \\
\hline 1985:1 dummy & 0.012610 & 0.007945 & 1.587151 & 0.1132 \\
\hline R-squared & 0.434554 & \multirow{4}{*}{\multicolumn{2}{|c|}{$\begin{array}{l}\text { Mean dependent var } \\
\text { S.D. dependent var } \\
\text { Sum squared resid }\end{array}$}} & 0.005675 \\
\hline Adjusted R-squared & 0.346717 & & & 0.010038 \\
\hline S.E. of regression & 0.008113 & & & 0.006780 \\
\hline Durbin-Watson stat & 2.205775 & & & \\
\hline
\end{tabular}




\begin{tabular}{crrrr}
$\Delta \mathbf{k}$ equation & & & & \\
FOC* & $\mathbf{0 . 0 0 1 7 5 3}$ & $\mathbf{0 . 0 0 0 6 7 8}$ & $\mathbf{2 . 5 8 6 1 2 9}$ & $\mathbf{0 . 0 1 0 0}$ \\
CAI* & $\mathbf{- 0 . 0 0 3 2 5 6}$ & $\mathbf{0 . 0 0 1 2 3 0}$ & $\mathbf{- 2 . 6 4 7 2 7 6}$ & $\mathbf{0 . 0 0 8 4}$ \\
$\Delta \mathrm{i}(-7)$ & 0.004755 & 0.001362 & 3.490259 & 0.0005 \\
$\Delta \mathrm{k}(-1)$ & 0.771877 & 0.059862 & 12.89432 & 0.0000 \\
$\Delta \mathrm{k}(-7)$ & -0.098471 & 0.030401 & -3.239111 & 0.0013 \\
Constant & 0.002899 & 0.000589 & 4.925946 & 0.0000 \\
1985:1 dummy & 0.001260 & 0.000523 & 2.407077 & 0.0165 \\
1985:1 dummy lagged & -0.002750 & 0.000516 & -5.334713 & 0.0000 \\
\hline \hline R-squared & 0.924283 & Mean dependent var & 0.009074 \\
Adjusted R-squared & 0.919550 & S.D. dependent var & 0.001883 \\
S.E. of regression & 0.000534 & Sum squared resid & $3.19 \mathrm{E}-05$ \\
Durbin-Watson stat & 2.032066 & & & \\
\hline * FOC and CAI defined as in table A3.
\end{tabular}

* FOC and CAI defined as in table A3.

One of the three WE restrictions from the Johansen estimation is rejected under SUR, namely that the $\mathrm{D}(\mathrm{k})$ equation is weakly exogenous to the FOC. For completeness we also tested down having already imposed the WE restrictions from the Johansen estimation. The results are shown in Table A5.

Table A5: SUR estimates, imposing WE

Estimation Method: Seemingly Unrelated Regression Sample: 1972:1 2002:1

\begin{tabular}{llll} 
Coefficient & Std. Error & t-Statistic & Prob. \\
\hline
\end{tabular}

\begin{tabular}{|c|c|c|c|c|}
\hline \multicolumn{5}{|l|}{$\Delta r$ equation } \\
\hline FOC* & 0.366559 & 0.059303 & 6.181118 & 0.0000 \\
\hline CAI* & 0.760880 & 0.171657 & 4.432568 & 0.0000 \\
\hline$\Delta \mathrm{r}(-1)$ & 0.206790 & 0.065760 & 3.144604 & 0.0018 \\
\hline$\Delta \mathrm{r}(-2)$ & -0.141701 & 0.066520 & -2.130187 & 0.0337 \\
\hline$\Delta \mathrm{r}(-3)$ & 0.162272 & 0.066682 & 2.433520 & 0.0154 \\
\hline$\Delta \mathrm{r}(-5)$ & -0.172814 & 0.062590 & -2.761060 & 0.0060 \\
\hline$\Delta \mathrm{r}(-8)$ & 0.324277 & 0.065198 & 4.973739 & 0.0000 \\
\hline$\Delta \mathrm{i}(-1)$ & 0.654098 & 0.192402 & 3.399648 & 0.0007 \\
\hline$\Delta \mathrm{i}(-2)$ & 0.692459 & 0.183299 & 3.777750 & 0.0002 \\
\hline$\Delta \mathrm{i}(-6)$ & -0.226286 & 0.096157 & -2.353300 & 0.019 \\
\hline$\Delta \mathrm{i}(-7)$ & 0.273851 & 0.098209 & 2.788461 & 0.0055 \\
\hline$\Delta \mathrm{y}(-1)$ & -0.740078 & 0.348115 & -2.125958 & 0.0341 \\
\hline$\Delta y(-3)$ & -0.716126 & 0.319294 & -2.242842 & 0.0254 \\
\hline$\Delta y(-5)$ & 0.695236 & 0.338845 & 2.051783 & 0.0408 \\
\hline$\Delta y(-6)$ & 1.069935 & 0.322404 & 3.318620 & 0.0010 \\
\hline$\Delta \mathrm{y}(-7)$ & 1.314250 & 0.317705 & 4.136700 & 0.0000 \\
\hline$\Delta \mathrm{k}(-3)$ & 36.81103 & 9.450115 & 3.895299 & 0.0001 \\
\hline$\Delta \mathrm{k}(-4)$ & -14.06410 & 6.024085 & -2.334645 & 0.0200 \\
\hline$\Delta \mathrm{k}(-5)$ & 11.68599 & 4.878103 & 2.395601 & 0.0170 \\
\hline Constant & -0.335916 & 0.082395 & -4.076924 & 0.0001 \\
\hline 1985:1 dummy lagged & 0.065349 & 0.032572 & 2.006295 & 0.0455 \\
\hline R-squared & 0.590046 & Mean depen & t var & -0.003242 \\
\hline Adjusted R-squared & 0.505519 & S.D. depend & var & 0.04698 \\
\hline S.E. of regression & 0.033039 & Sum square & sid & 0.10588 \\
\hline Durbin-Watson stat & 2.021798 & & & \\
\hline$\Delta \mathrm{i}$ equation & & & & \\
\hline FOC* & 0.035900 & 0.018521 & 1.938377 & 0.053 \\
\hline$\Delta \mathrm{i}(-7)$ & 0.246963 & 0.070791 & 3.488628 & 0.000 \\
\hline$\Delta \mathrm{y}(-5)$ & 0.507487 & 0.244492 & 2.075675 & 0.038 \\
\hline$\Delta \mathrm{k}(-7)$ & -3.181295 & 0.847400 & -3.754181 & 0.0002 \\
\hline
\end{tabular}




\begin{tabular}{lrrrr}
\multicolumn{1}{c}{ Constant } & 0.031369 & 0.008447 & 3.713605 & 0.0002 \\
1985:1 dummy & 0.085672 & 0.027805 & 3.081121 & 0.0022 \\
1985:1 dummy lagged & -0.144194 & 0.026819 & -5.376539 & 0.0000 \\
\hline \hline R-squared & 0.348161 & Mean dependent var & 0.008007 \\
Adjusted R-squared & 0.313854 & S.D. dependent var & 0.035112 \\
S.E. of regression & 0.029084 & Sum squared resid & 0.096433 \\
Durbin-Watson stat & 2.092715 & & \\
\hline \hline
\end{tabular}

\begin{tabular}{|c|c|c|c|c|}
\hline \multicolumn{5}{|l|}{$\Delta y$ equation } \\
\hline FOC* & 0.046446 & 0.011189 & 4.151233 & 0.0000 \\
\hline$\Delta \mathrm{r}(-3)$ & -0.056113 & 0.014618 & -3.838603 & 0.0001 \\
\hline$\Delta \mathrm{r}(-6)$ & -0.028991 & 0.014985 & -1.934637 & 0.0537 \\
\hline$\Delta \mathrm{i}(-1)$ & 0.154573 & 0.043683 & 3.538488 & 0.0004 \\
\hline$\Delta \mathrm{i}(-2)$ & 0.089221 & 0.042909 & 2.079302 & 0.0382 \\
\hline$\Delta \mathrm{i}(-3)$ & 0.071899 & 0.040640 & 1.769169 & 0.0776 \\
\hline$\Delta \mathrm{i}(-4)$ & -0.135324 & 0.050697 & -2.669267 & 0.0079 \\
\hline$\Delta \mathrm{i}(-5)$ & -0.097782 & 0.048345 & -2.022603 & 0.0437 \\
\hline$\Delta \mathrm{i}(-6)$ & 0.069547 & 0.020532 & 3.387217 & 0.0008 \\
\hline$\Delta \mathrm{i}(-8)$ & 0.056466 & 0.021333 & 2.646850 & 0.0084 \\
\hline$\Delta y(-1)$ & -0.136248 & 0.076337 & -1.784822 & 0.0750 \\
\hline$\Delta y(-3)$ & 0.133514 & 0.077545 & 1.721760 & 0.0858 \\
\hline$\Delta y(-4)$ & -0.221191 & 0.077614 & -2.849899 & 0.0046 \\
\hline$\Delta y(-8)$ & -0.182464 & 0.071028 & -2.568890 & 0.0105 \\
\hline$\Delta \mathrm{k}(-1)$ & -6.387601 & 2.096837 & -3.046303 & 0.0025 \\
\hline$\Delta \mathrm{k}(-4)$ & 11.49030 & 2.903817 & 3.956965 & 0.0001 \\
\hline$\Delta \mathrm{k}(-6)$ & -6.693892 & 2.494748 & -2.683193 & 0.0076 \\
\hline Constant & 0.020021 & 0.004526 & 4.423608 & 0.0000 \\
\hline 1985:1 dummy & 0.014561 & 0.007776 & 1.872519 & 0.0618 \\
\hline R-squared & 0.451309 & \multicolumn{2}{|c|}{ Mean dependent var } & 0.005675 \\
\hline Adjusted R-squared & 0.353522 & \multicolumn{2}{|c|}{ S.D. dependent var } & 0.010038 \\
\hline S.E. of regression & 0.008071 & \multicolumn{2}{|c|}{ Sum squared resid } & 0.006579 \\
\hline Durbin-Watson stat & 1.990839 & & & \\
\hline \multicolumn{5}{|l|}{$\Delta \mathrm{k}$ equation } \\
\hline CAI* & -0.004398 & 0.001237 & -3.555343 & 0.0004 \\
\hline$\Delta \mathrm{i}(-7)$ & 0.003733 & 0.001368 & 2.729027 & 0.0066 \\
\hline$\Delta y(-4)$ & 0.004722 & 0.002404 & 1.964656 & 0.0501 \\
\hline$\Delta y(-5)$ & 0.011286 & 0.004620 & 2.443095 & 0.0150 \\
\hline$\Delta \mathrm{k}(-1)$ & 0.718512 & 0.068030 & 10.56169 & 0.0000 \\
\hline Constant & 0.002409 & 0.000621 & 3.881169 & 0.0001 \\
\hline 1985:1 dummy & 0.001469 & 0.000529 & 2.777934 & 0.0057 \\
\hline 1985:1 dummy lagged & -0.002465 & 0.000513 & -4.800954 & 0.0000 \\
\hline R-squared & 0.919255 & \multicolumn{2}{|c|}{ Mean dependent var } & 0.009074 \\
\hline Adjusted R-squared & 0.914208 & \multicolumn{2}{|c|}{ S.D. dependent var } & 0.001883 \\
\hline S.E. of regression & 0.000551 & \multicolumn{2}{|c|}{ Sum squared resid } & $3.41 \mathrm{E}-05$ \\
\hline Durbin-Watson stat & 1.932705 & & & \\
\hline
\end{tabular}

* FOC and CAI defined as in table A3. 